\title{
Review
}

\section{Alternatives to antibiotics for maximizing growth performance and feed efficiency in poultry: a review}

\author{
U. Gaddet, W. H. Kimt, S. T. Oht and Hyun S. Lillehoj* \\ Animal Biosciences and Biotechnology Laboratory, Beltsville Agricultural Research Center, \\ Agricultural Research Service, USDA, Beltsville, MD 20705, USA
}

Received 18 October 2016; Accepted 13 December 2016; First published online 9 May 2017

\begin{abstract}
With the increase in regulations regarding the use of antibiotic growth promoters and the rise in consumer demand for poultry products from 'Raised Without Antibiotics' or 'No Antibiotics Ever' flocks, the quest for alternative products or approaches has intensified in recent years. A great deal of research has focused on the development of antibiotic alternatives to maintain or improve poultry health and performance. This review describes the potential for the various alternatives available to increase animal productivity and help poultry perform to their genetic potential under existing commercial conditions. The classes of alternatives described include probiotics, prebiotics, synbiotics, organic acids, enzymes, phytogenics, antimicrobial peptides, hyperimmune egg antibodies, bacteriophages, clay, and metals. A brief description of the mechanism of action, efficacy, and advantages and disadvantages of their uses are also presented. Though the beneficial effects of many of the alternatives developed have been well demonstrated, the general consensus is that these products lack consistency and the results vary greatly from farm to farm. Furthermore, their mode of action needs to be better defined. Optimal combinations of various alternatives coupled with good management and husbandry practices will be the key to maximize performance and maintain animal productivity, while we move forward with the ultimate goal of reducing antibiotic use in the animal industry.
\end{abstract}

Keywords: poultry, antibiotic alternatives, performance.

\section{Introduction}

Since the discovery of antibiotics in the 1920 s, they have played a substantial role in the advancement and prosperity of the poultry industry. Antibiotics have been supplemented in animal feed at sub-therapeutic doses to improve growth and feed conversion efficiency and to prevent infections for more than 60 years (Castanon, 2007). The effect of antibiotics on improving

*Corresponding author. E-mail: hyun.lillehoj@ars.usda.gov tOak Ridge Institute for Science and Education (ORISE) Research Fellow at the Animal Biosciences and Biotechnology Laboratory, Beltsville Agricultural Research Center, Agricultural Research Service, USDA, Beltsville, MD 20705, USA. performance was first reported by Moore et al. (1946) when they observed that birds fed streptomycin exhibited increased growth responses. Many experiments conducted later in the early 1950s in chickens (Groschke and Evans, 1950; McGinnis, 1950; Whitehill et al., 1950), pigs (Jukes et al., 1950; Luecke et al., 1950a, b), and calves (Rusoff et al., 1951) corroborated these results. In-feed antibiotic (IFA) use soon became a common and well-established practice in the animal industry and rose with the intensification of livestock production. In a review conducted by Rosen (1995), it was concluded that inclusion of antibiotics in the diets gave a positive response $72 \%$ of the time. It was also proposed that the net effect of using IFA in the poultry industry was a $3-5 \%$ increase in growth and feed conversion efficiency (Choct, 2001; Dahiya et al., 2006). Thus, it can be noted that IFA played a crucial role in contributing to the economic 
effectiveness of the livestock production (Wierup, 2000). Despite the well-demonstrated beneficial effects of IFA in improving the growth rate, reducing the mortality and increasing resistance to disease challenge, their use was also known to be associated with some disadvantages and challenges. Concerns exist that the use of IFA leads to development of antimicrobial resistance, posing a potential threat to human health (WHO, 2012). However, mixed opinions still exist on the transfer of antibiotic resistance genes from animal to human pathogens. Several studies showed that there might be a link between the practice of using subtherapeutic antibiotics and the development of antimicrobial resistance among the microflora (Endtz et al., 1990; Witte, 1998; Wegener et al., 1999; Greko, 2001; M'ikanatha et al., 2010; Medeiros et al., 2011; Cosby et al., 2015).

Despite these debates on the role of IFA use in conferring antimicrobial resistance to human pathogens, the European Union issued a ban on the approval for antibiotics as growth promoters since 1 January 2006 on precautionary grounds (Dibner and Richards, 2005; Castanon, 2007). In the USA, antibiotic use in livestock and poultry feeds is under great scrutiny as a result of increasing consumer awareness and the demand for livestock products from antibiotic-free production systems. In 2013, the US Food and Drug Administration (FDA) called for major manufacturers of medically important animal drugs to voluntarily stop labeling them for growth promotion in animals and revise the labels such that veterinary supervision is required for therapeutic uses (GFI\#213; FDA, 2013). FDA continued to strengthen its agenda on promoting judicious use of antimicrobials in food-producing animals and published its final rule of the VFD (Veterinary Feed Directive) in early 2015 , bringing the use of medically important antimicrobials in feed under veterinary supervision, so that they are used only when necessary to ensure the health of the animals. In late 2015, the state of California passed a bill (Senate Bill 27) enforcing a strict ban on using medically important antimicrobials in animal feeds for both growth promotion and disease prevention.

The decline in the use of antibiotic growth promoters (AGPs) in the future seems inevitable, and the practice of using antimicrobials may prove economically impractical because of market limitations and export restrictions (Dibner and Richards, 2005). In view of the increasing concerns over AGP use, the quest for novel alternate replacements to mitigate antibiotic use in animal agriculture has grown over the years. In the past two decades, a great deal of research has focused on the development of antibiotic alternatives to maintain or improve poultry health and performance. This review, therefore, is focused on current knowledge pertaining to several of the strategies that are being employed to improve poultry growth performance and provides a brief overview of such alternatives along with a description of their efficacy and modes of action.

\section{Mechanism of action of AGPs}

The successful development of antibiotic alternatives, at least to some extent, relies on understanding the mechanism of action of AGPs. Several ideas have been proposed to elucidate the rationale behind antibiotic-mediated growth enhancement, but to date there is no clear-cut explanation. Preliminary theories have linked their efficacy to their antibacterial action, which was thought to be mediated by a reduction in the overall numbers or diversity of the gut microbiota (Francois, 1961; Visek, 1978), resulting in decreased competition for nutrients and reduced microbial metabolites that affect growth (amino acid and bile catabolism) (Feighner and Dashkevicz, 1987; Gaskins et al., 2002; Knarreborg et al., 2004). This theory was contradicted by Niewold (2007), who proposed that the beneficial effects of antibiotics are due to their interaction with host immune cells rather than the growth inhibitory effects on microbiota. He hypothesized that antibiotics lower the inflammatory response and thus the production of proinflammatory cytokines, which reduce the appetite and promote muscle catabolism. The anti-inflammatory role of AGP reduces wasted energy and directs it toward production (Niewold, 2007).

Though a clear consensus on how AGP acts still does not exist in the scientific community, it is now clear - with the advent of novel molecular biology and bioinformatics techniques - that shifts in microbiota composition (structure and diversity) do occur when antibiotics are included in animal diets (Dumonceaux et al., 2006; Pedroso et al., 2006; Wise and Siragusa, 2007; Lin et al., 2013). These shifts may ultimately result in an optimal and balanced microbiota that is less capable of evoking an inflammatory response, increases energy harvest from nutrients, and helps animals perform to their genetic potential (Huyghebaert et al., 2011; Lin, 2011). However, it still remains challenging to definitively link-specific bacterial populations to enhanced growth and pinpoint ways/tools to modify microbiota to a desired one (Lin, 2014). A few research trials were conducted to associate bacterial products or enzymes to enhanced performance, and have shown a decrease in bile salt hydrolase (BSH) enzyme activity in the gut. It was proposed that BSH produced by gut bacteria catalyzes deconjugation of bile acids and alters host lipid metabolism, and AGPs acts by reducing the number of bacteria that are producing BSH (Feighner and Dashkevicz, 1987; Knarreborg et al., 2004; Guban et al., 2006; Lin, 2014). Recent studies conducted in mice revealed that exposure to sub-therapeutic antibiotic levels not only altered the composition of gut microbiota, but also their metabolic capability by selecting for microbial species that were capable of extracting a high proportion of calories from complex carbohydrates (increase in copies of genes involved in metabolism of carbohydrates to short-chain fatty acids (SCFA)) (Cho et al., 2012). The growth-promotion phenotype was shown to be transferrable to germ-free hosts by low-dose antibiotic-selected microbiota, indicating that the altered microbiota and not the antibiotics played a causal role (Cho et al., 2012). It was also shown from the studies in mice that exposure to low-dose antibiotics early in life induces long-term host metabolic effects by accelerating normal age-related microbiota development and altering ileal expression of the genes involved in immunity (Cox et al., 2014). Though the effects observed in mice cannot be directly extrapolated to farm animals, they might provide an insight into a possible mechanism of action. 


\section{Classes of alternatives}

An ideal alternative should have the same beneficial effects of AGP, ensure optimum animal performance, and increase nutrient availability (Huyghebaert et al., 2011). Considering the proposed mechanism of action of AGPs (microbiome and immune-modulating activities), a practical alternative should possess both of these properties in addition to having a positive impact on feed conversion and/or growth (Huyghebaert et al., 2011; Seal et al., 2013). Several classes of alternatives have been proposed and tested in poultry production, including probiotics, prebiotics, synbiotics, organic acids, enzymes, phytogenics and metals. Novel alternatives such as hyperimmune egg yolk IgY, antimicrobial peptides (AMP), bacteriophages, and clay have come into existence in recent years.

\section{Probiotics}

Probiotics, sometimes used interchangeably with the term direct fed microbials (DFMs), are gaining acceptance as potential alternatives to antibiotics to improve production efficiency (Lee et al., 2010c). They are defined as "live microbial feed supplements which beneficially affect the host animal by improving its intestinal microbial balance" (Fuller, 1989). A recent definition adopted by FAO/WHO (2001) states that "Probiotics are mono or mixed cultures of live organisms which when administered in adequate amounts confer a health benefit to the host." Probiotics may contain one or more strains of microorganisms and may be given either alone or in combination with other additives in feed or water (Thomke and Elwinger, 1998). Novel application strategies such as spraying on chicks or embryonated eggs are also practiced and potential methods such as in-ovo application are being explored (Wolfenden et al., 2007; Cox and Dalloul, 2015).

A variety of bacteria (Bacillus, Bifidobacterium, Enterococcus, Lactobacillus, Streptococcus, and Lactococcus spp.) and in some cases yeast (Saccharomyces spp.) have been tested as probiotics in poultry (Simon et al., 2001; Patterson and Burkholder, 2003; Griggs and Jacob, 2005; Kabir, 2009). The majority of the conducted research was specifically aimed at investigating the effects of probiotics in reducing the numbers of pathogenic microorganisms in the gastrointestinal tract. However, a considerable amount of research also examined the effects of probiotics on improving growth and performance in poultry without apparent disease. Supplementation of diets with a single strain of Lactobacillus sp. (L. casei, L. fermentum, L. bulgaricus, L. reuteri) was shown to improve the body weight and feed efficiency in broilers (Yeo and Kim, 1997; Khan et al., 2007; Apata, 2008; Nakphaichit et al., 2011; Salim et al., 2013). Similar results were shown when broilers were given multiple strains of Lactobacillus sp. (Jin et al., 1998; Kalavathy et al., 2003; Mookiah et al., 2014). Bacillus sp.-based probiotics (B. coagulans, B. subtilis, B. licheniformis, and B. amyloliquefaciens) were also successfully employed in poultry diets and were shown to have growth-promoting effects (Cavazzoni et al., 1998; Lee et al., 2010a, 2011a; Wang and Gu, 2010; Liu et al., 2012; Sen et al., 2012; Ahmed et al., 2014; Jeong and Kim, 2014; Park and
Kim, 2014). The application of several other probiotic bacteria such as Enterococcus faecium (Samli et al., 2007; Kabir et al., 2004), Clostridium butyricum (Yang et al., 2012; Zhao et al., 2013a; Liao et al., 2015), Rhodopseudomonas palustris (Xu et al., 2014) also significantly increased the daily weight gains with decreased feed conversion ratio (FCR). Research trials have also been conducted with multi-microbe probiotic mixtures composed of combinations of different beneficial bacteria and/or yeast and were shown to exhibit a growth-promoting effect (Chiang and Hsieh, 1995; Huang et al., 2004; Mountzouris et al., 2007, 2010; Nayebpor et al., 2007; Talebi et al., 2008; Torshizi et al., 2010; Kim et al., 2012; Bai et al., 2013; Alimohamadi et al., 2014; Zhang and Kim, 2014). Faria Filho et al. (2006) performed a meta-analysis of 27 studies involving 30,146 broiler chickens that were conducted in Brazil during 1995-2005 to investigate the performance effects of 12 different probiotics. The results of their analysis showed that overall the probiotic supplementation improved the body weight gain by 0.14 and reduced FCR by 0.10 points compared with nonsupplemented controls. A similar meta-analysis of several randomized controlled research trials that were carried out from 1980 to 2012 was conducted by Blajman et al. (2014) to investigate the effects of probiotics on body weight gain and feed efficiency in broilers. They concluded that probiotics inclusion increased body weight gain and improved feed efficiency, and also showed that probiotics application via water was more efficacious than through feed. The analysis also showed that there were no differences between the use of mono- or multi-strain probiotics and the effects observed may vary with the type of strain used.

In addition to the improved growth performance, probiotics supplementation was also shown to enhance the general immune function of broilers, as evidenced by the augmented serum/plasma immunoglobulin levels, increased antibody titers to pathogens, and changes in immune cell numbers (Nayebpor et al., 2007; Apata, 2008; Lee et al., 2011a; Bai et al., 2013; Salim et al., 2013; Ahmed et al., 2014). The intestines of broilers that were given probiotics showed better development and an increase in villus height and crypt depth compared with controls (Samli et al., 2007; Lee et al., 2010a, 2011a; Kim et al., 2012; Sen et al., 2012). Probiotics supplementation also positively modulated the intestinal microbiota and increased numbers of beneficial bacteria such as Lactobacillus and Bifidobacterium spp. (Mountzouris et al., 2007, 2010; Samli et al., 2007; Nakphaichit et al., 2011; Yang et al., 2012; Jeong and Kim, 2014; Mookiah et al., 2014; Zhang and Kim, 2014).

The beneficial effects of probiotics supplementation were also reported in laying hens. Kurtoglu et al. (2004) showed that hens fed diets supplemented with probiotics showed increased egg production compared with controls. Lei et al. (2013) reported that dietary inclusion of B. licheniformis improved laying performance and egg mass. Consistent with these findings, various DFM product supplementation was also shown to improve body weight and performance in turkeys (Russell and Grimes, 2009; Wolfenden et al., 2011). Lactobacillus-based probiotics significantly improved market body weight and average daily gain of commercial turkeys (Torres-Rodriguez et al., 2007). Albeit numerous publications show the performance improvement in 
broilers, layers, and turkeys, reports also exist that probiotics show limited and variable growth-promoting effect and in some instances none (Karaoglu and Durdag, 2005; O’Dea et al., 2006; Lee et al., 2010a; Waititu et al., 2014). This inconsistency in the results can be attributed to the differences in the type and dose of strain used, processing variations, administration time and period, diet, and environment.

Although the modes of action by which probiotics improve performance and promote gut health are not completely understood, a few have been proposed and reviewed (Edens, 2003; Parvez et al., 2006; Kabir, 2009; Ng et al., 2009; Vilà et al., 2010; Lee et al., 2010a). The two most important mechanisms through which probiotics exert beneficial effects include balancing the gut microflora and immune regulation. Probiotics help establish a microenvironment in the gut that favors beneficial microorganisms and reduces the colonization of pathogenic bacteria (competitive exclusion) by: (1) creating a hostile environment for harmful bacterial species (through production of lactic acid, SCFA, and reduction in $\mathrm{pH}$ ); (2) competing for nutrients with undesired bacteria; (3) production and secretion of antibacterial substances (e.g. bacteriocins by Lactobacillus, Bacillus spp.); and (4) inhibition of bacterial adherence and translocation (Nurmi and Rantala, 1973; Fuller, 1989; Netherwood et al., 1999; Schneitz, 2005; Ng et al., 2009; Brown, 2011). Probiotics are also known to improve intestinal function by maintaining epithelial cell homoeostasis, promoting cytoprotective responses and cell survival (through production of cytokines that enhance epithelial cell regeneration and inhibit apoptosis), improving barrier function (modulation of cytoskeletal and epithelial tight junctions), and increasing mucin synthesis (Chichlowski et al., 2007; Ng et al., 2009; Brown, 2011). They also play an important role in digestion and nutrient retention by increasing digestive enzyme activity and improving the breakdown of indigestible nutrients (Jin et al., 2000; Ciorba, 2012; Ng et al., 2009; Wang and Gu, 2010). Probiotics also exert their action by reducing toxic amine production and ammonia levels in the gut (Chiang and Hsieh, 1995). Another important mechanism of probiotics action includes modulating and regulating intestinal immune responses by reducing pro-inflammatory cytokines, increasing secretory IgA production, and promoting specific and non-specific immune responses against pathogens (activation of macrophages, increase cytokine production by intraepithelial lymphocytes) (Ng et al., 2009; Lee et al., 2010a, 2011a).

Thus, an ideal probiotic organism should be able to withstand processing and storage, survive in the gastric acidic environment, adhere to epithelium or mucus in the intestines, produce antimicrobial compounds, and modulate immune responses (Edens, 2003; Patterson and Burkholder, 2003; Cheng et al., 2014). However, not all strains exhibit all of the above properties and care must be taken to select the strains or their combinations that will achieve maximum beneficial effect in vivo. Measures to protect the organisms during their passage through the upper alimentary tract such as a microencapsulation should be considered to ensure viability and colonization in the intestine (Han et al., 2013). Overall, it can be said that probiotics can serve as potential alternatives to antibiotics for increasing poultry performance.

\section{Prebiotics}

Prebiotics are defined as 'non-digestible feed ingredients that beneficially affect the host by selectively stimulating the growth and/or activity of one or a limited number of bacteria in the gut' (Gibson and Roberfroid, 1995; Patterson and Burkholder, 2003). A recent definition (FAO, 2007) describes prebiotics as 'non-viable feed components that confer a health benefit on the host associated with modulation of the microbiota.' A variety of non-starch polysaccharides (NSP) or oligosaccharides have been considered as prebiotics, including mannan oligosaccharide (MOS), fructooligosaccharide (FOS), inulin, oligofructose, galactooligosaccharide, maltooligosaccharide, lactulose, lactitol, glucooligosaccharide, xylooligosaccharide, soya-oligosaccharide, isomaltooligosaccharide (IOS), and pyrodextrins (Patterson and Burkholder, 2003; Steiner, 2006).

Prebiotics are macromolecules that are either derived from plants or synthesized by microorganisms. MOS, derived from the outer cell-wall layer of Saccharomyces cerevisiae, has been studied extensively as a prebiotic supplement in poultry diets. The addition of various levels of MOS to the broiler diets significantly increased their body weight and improved feed conversion efficiency (Benites et al., 2008; Bozkurt et al., 2008; Hooge et al., 2003; Yang et al., 2007; Mohamed et al., 2008) with increased intestinal villi height (Baurhoo et al., 2007; Yang et al., 2007), improved immune-competence in the intestine (Janardhana et al., 2009; Shanmugasundaram and Selvaraj, 2012), altered jejunal gene expression (Xiao et al., 2012; Brennan et al., 2013), and influenced intestinal microbiota (Geier et al., 2009; Corrigan et al., 2011; Kim et al., 2011; Pourabedin et al., 2014). FOS, which is derived from plants, has also been shown to possess significant prebiotic effect and improve performance in broiler chickens (Xu et al., 2003; Kim et al., 2011). Another class of prebiotics includes IOS showing promise as an antibiotic alternative owing to their efficacy in improving weight gain and FCR when fed to broilers (Mookiah et al., 2014).

Lactulose is a non-digestible, synthetic disaccharide that was also proven to show prebiotic effect in humans and pigs. Calik and Ergün (2015) showed that lactulose supplementation in broiler diets not only improved body weight and FCR, but also increased villi height, goblet cell numbers, total SCFA concentrations, and Lactobacillus counts. Similar results of improvement in FCR and Lactobacillus counts with lactulose supplementation were shown by Cho and Kim (2014). Various other prebiotics that were tested and found to be beneficial in poultry include lignin (Baurhoo et al., 2007), inulin (Alzueta et al., 2010; Rebolé et al., 2010), and palm kernel extract (Rezaei et al., 2015). In contrast to the previous results, several authors reported that prebiotic supplementation had no effect on performance (Baurhoo et al., 2007; Józefiak et al., 2008; Geier et al., 2009; Corrigan et al., 2011; Houshmand et al., 2012). However, statistical analysis of numerous trials conducted with prebiotic supplementation in the diets of broiler chickens was shown to beneficially influence their growth and performance. Holo- and meta-analysis of several research trials conducted over the years using prebiotics in feed have confirmed 
these effects (Hooge, 2004; Rosen, 2007; Hooge and Connolly, 2011). It was shown that adding a yeast cell-wall product to the diets significantly improved body weight by $1.61 \%$ and reduced FCR by $1.99 \%$, respectively (Hooge, 2004). Hooge and Connolly (2011) reported that prebiotics improved body weight by $5.41 \%$, decreased FCR by $2.54 \%$, and reduced mortality by $10.5 \%$.

A number of characteristics should be taken into consideration when selecting prebiotics, including resistance to gastric acidic environment, intestinal/pancreatic enzyme hydrolysis, and absorption across intestinal epithelium (Hume, 2011; Heo et al., 2013; Ricke, 2015). The most important characteristic of an ideal prebiotic is the ability to selectively enrich beneficial microorganisms associated with health and well-being (Simmering and Blaut, 2001; Patterson and Burkholder, 2003; Heo et al., 2013; Samantha et al., 2013). Thus, the majority of the beneficial effects of prebiotics are thought to be mediated predominantly through altering the intestinal microbiota (Pourabedin and Zhao, 2015). Prebiotics also prevent pathogen colonization either by binding directly or by competitive exclusion by promoting the growth of beneficial microbes or by stimulating them to produce bacteriocins and lactic acid (Spring et al., 2000). In particular, MOS acts by binding to type 1 fimbriae of enteric pathogens and prevents their adhesion to intestinal epithelial cells (Spring et al., 2000). The fermentation of prebiotics by microflora also leads to the production of SCFA that act as energy sources for intestinal epithelial cells and thus maintain the integrity of the gut lining (Ferket et al., 2005). Prebiotics also act by beneficially altering luminal or systemic aspects of the host immune system. MOS is recognized by receptors of the innate immune system, act as adjuvants, and help boost the host immune responses (Ferket et al., 2005).

\section{Synbiotics}

Synbiotics are additives that combine the use of probiotics and prebiotics such that they act synergistically (Alloui et al., 2013). The use of synbiotics was based on the concept that a mixture of probiotics and prebiotics beneficially affect the host by improving the survival and implantation of probiotic organisms and by selectively promoting the growth or metabolism of beneficial bacteria in the intestinal tract (Gibson and Roberfroid, 1995). Few research trials have been conducted to demonstrate the effects of synbiotics on broiler performance. Supplementation of diets with a synbiotic product was shown to significantly improve body weight, average daily gain, feed efficiency, and carcass yield percentage compared with controls or probiotic-fed broilers (Awad et al., 2009). Ashayerizadeh et al. (2009) reported similar improvement in growth indices and Mohnl et al. (2007) showed that synbiotics increased body weight by $2.04 \%$ and reduced mortality by $0.9 \%$ compared with controls. Mookiah et al. (2014) reported a significant increase in weight gain and a decrease in the FCR when birds were fed diets with a combination of IOS and probiotic mixture (11 strains of Lactobacillus spp.). However, the synbiotic did not show a 2-fold synergistic effect compared with those of prebiotics or probiotics alone. A combination of yeast-derived carbohydrates and probiotics was shown to increase body weight gain compared with controls or prebiotic-supplemented pullets (Yitbarek et al., 2015). In contrast, some of the trials conducted with in-feed inclusion of synbiotics did not show that performance was affected (Willis et al., 2007; Jung et al., 2008). Synbiotics were also shown to beneficially alter the intestinal microbiota composition and increase villi height and crypt depth in the intestinal mucosa (Jung et al., 2008; Awad et al., 2009; Sohail et al., 2012). There is a great potential for synbiotics to be used as antibiotic alternatives for improving performance and reducing pathogenic load in the intestines of poultry. Careful consideration must be given when selecting the combinations of various prebiotics and probiotics to be used as synbiotics, and research trials should be conducted to demonstrate their synergistic effect compared with the use of either product alone (Fig. 1).

\section{Organic acids}

Dietary organic acids have been considered as potential alternatives to AGPs, owing to their antibacterial nature. Chemically, organic acids used in food animal production can be described as either simple monocarboxylic acids (e.g., formic, acetic, propionic, and butyric acids) or carboxylic acids bearing hydroxyl group (e.g., lactic, malic, tartaric, and citric acids) (Dibner and Buttin, 2002). They are widely distributed in nature as normal constituents of animal or plant tissues and some of them (specifically SCFA) are produced in the hind gut of food animals and humans through microbial fermentation of carbohydrates (Van Der Wielen et al., 2000; Ricke, 2003; Huyghebaert et al., 2011). They can be administered in the feed or drinking water and can be used either individually as organic acids or their salts (sodium, potassium, or calcium) or as blends of multiple acids or their salts (Huyghebaert et al., 2011).

Organic acid use has been shown to have significant benefits in swine and poultry production over the years. Dietary supplementation of fumaric acid in broiler chickens was shown to improve weight gain and feed efficiency (Patten and Waldroup, 1988; Skinner et al., 1991; Biggs and Parsons, 2008; Adil et al., 2010, 2011; Banday et al., 2015). Similar effects of growth performance improvement were seen when butyric acid was included in the broiler feed (Panda et al., 2009; Adil et al., 2010, 2011). Several other organic acids that were tested and shown to improve performance in poultry include lactic (Adil et al., 2010, 2011), citric (Chowdhury et al., 2009; Haque et al., 2010; Salgado-Tránsito et al., 2011), formic (Patten and Waldroup, 1988; Hernández et al., 2006; Panda et al., 2009), malic, sorbic, and tartaric acids. Research has shown that the beneficial effects of organic acids can be enhanced by using them as blends rather than a single acid. Various organic acid blends were tested and shown to improve the FCR in broiler chickens (Samanta et al., 2008, 2010).

Though the mechanism of action of organic acids is not clearly understood, it can be attributed to their antibacterial activity. Several possible mechanisms include the following: (1) reducing the $\mathrm{pH}$ level of the upper gastrointestinal tract (crop, 


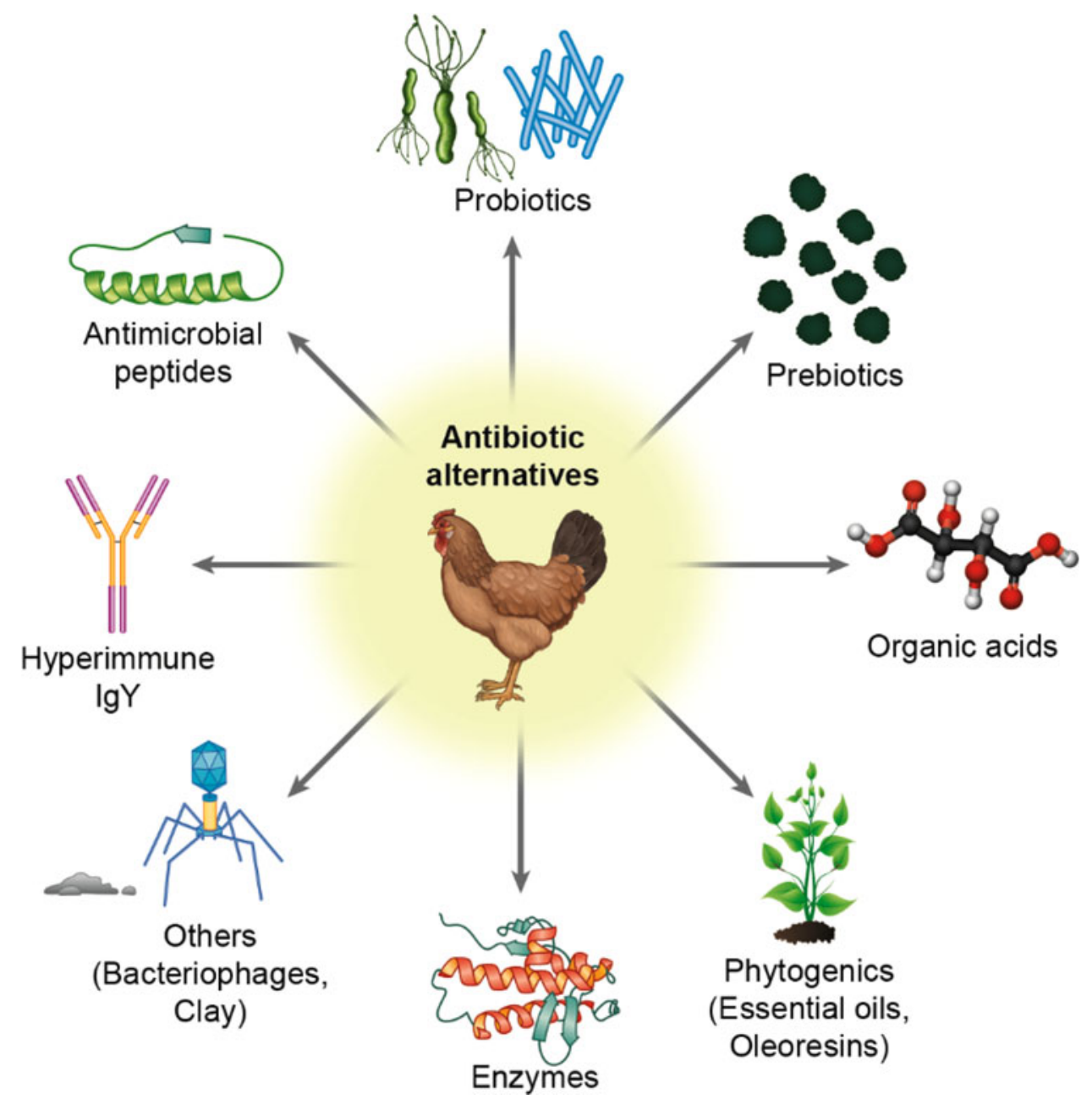

Fig. 1. Various classes of antibiotic alternatives that are available for use in poultry production.

proventriculus, gizzard) and associated physiological changes in the gut mucosa (Samanta et al., 2008; Panda et al., 2009); (2) altering the gut microflora either by directly killing through cell-wall penetration or by indirectly modifying $\mathrm{pH}$ and reducing the numbers of pathogenic bacteria, increasing acidtolerant beneficial species such as Lactobacilllus spp. and reducing competition for nutrients by the altered microbes (Biggs and Parsons, 2008; Nava et al., 2009; Czerwiński et al., 2010; Boroojeni et al., 2014); (3) increasing nutrient digestibility by elevating protein and dry matter retention, improving mineral absorption and phosphorous utilization (Rafacz-Livingston et al., 2005; Nezhad et al., 2011); and (4) improving gut health through direct effects on epithelial cells (e.g. SCFA are a direct energy source for the growth of epithelial cells). In spite of the demonstrated beneficial effects, using organic acids to improve performance lacks consistency. This can be attributed to various factors such as inclusion rates, the source of the organic acids, and the buffering capacity of other dietary ingredients (Dibner and Buttin, 2002; Kim et al., 2015). Further research should address inconsistency issues and understand their mechanism of action to develop organic acids as effective antibiotic replacements.

\section{Enzymes}

Dietary enzymes are biologically active proteins that facilitate chemical breakdown of nutrients to smaller compounds for further digestion and absorption (Thacker, 2013). Various enzymes, derived from microbes (bacteria and fungi) through fermentation, have been used in swine and poultry feeds for the past several years, and their value in enhancing growth and feed efficiency is well noted. The different classes of enzymes commonly employed include phytase, carbohydrases (xylanase, cellulase, $\alpha$-galactosidase, $\beta$-mannanase, $\alpha$-amylase, and pectinase), and proteases. The effect of various in-feed enzymes in improving the growth and feed efficiency in poultry is well documented and reviewed (Bedford and Schulze, 1998; Choct, 2006; Selle and Ravindran, 2007; Adeola and Cowieson, 2011; Slominski, 2011; Woyengo and Nyachoti, 2011).

It is now well accepted that exogenous enzymes act on antinutritional factors that are present in plant-based feedstuffs such as phytic acid, NSP, and cell-wall complex carbohydrates. The improved performance that is a result of enzyme supplementation thus has been linked to an increase in the overall 
digestibility and availability of nutrients for absorption (Bedford, 2000; Verstegen and Williams, 2002; Rebolé et al., 2010). The possible mechanisms of action of in-feed enzymes include the following: (1) increase in the digestibility of nutrients that are otherwise not degraded by host enzymes (e.g. phytic acid); (2) elimination of the nutrient-encapsulating effect of cell-wall polysaccharides and an increase in the availability of starches, amino acids, and minerals; (3) inactivation of anti-nutritional factors (e.g., phytic acid or soluble NSP) and reduced intestinal viscosity; (4) an increase in the solubility of non-soluble NSP and promotion of cecal fermentation; and (5) supplementation of endogenous enzymes that may be in insufficient amounts, especially in young animals in which the digestive system is not fully developed (Choct, 2009; Kiarie et al., 2013). In addition to the effects enzymes have on nutrient digestibility, they are also thought to influence the composition of the gut microbiota. The enzyme-induced microbiota changes are mostly indirect and are thought to be mediated by two main mechanisms: (1) reducing the undigested substrates and (2) generating short-chain oligosaccharides from cell-wall NSP with potential prebiotic effects (Bedford, 2000; Bedford and Cowieson, 2012; Kiarie et al., 2013). These mechanisms influence the nutrient supply and intestinal environment thus altering selection pressures on bacterial species (Bedford and Cowieson, 2012; Cheng et al., 2014).

The potential for use of in-feed enzymes, as antibiotic alternatives, to improve performance in poultry is significant. Various meta-analyses conducted corroborate these beneficial effects in broilers upon enzyme supplementation. A metaanalysis performed by Hooge et al. (2010) showed that supplementation of a dietary multi-enzyme complex involving phytase and NSP enzymes improved final body weight by $3.73 \%$ and lowered FCR by $2.64 \%$. Jackson and Hanford (2014) conducted a meta-analysis of seven pen trials investigating the effects of $\beta$-mannanase supplementation in male broilers raised to market age. They reported that the weight gain and FCR, analyzed across trials, were improved by $4.2 \%$ and 4.8 points, respectively, and concluded that $\beta$-mannanase supplementation is effective in broilers. A similar meta-analysis conducted by Swann and Romero (2014) investigated the beneficial effects of a xylanase, amylase, and protease combination. Their results, based on ten broiler studies, showed that the particular enzyme combination increased the apparent digestibility of undigested crude protein, starch and fat by $22.7,88.9$, and $33.4 \%$, respectively. However, it should be noted that the beneficial effects of enzyme supplementation are sometimes inconsistent owing to the differences in the enzyme type, source, amount of enzyme used, presence of enzyme side effects, diet composition, and genetic variations among animals (Ravindran and Son, 2011; Cheng et al., 2014).

\section{Phytogenics}

Phytogenic feed additives (PFAs), also referred as phytobiotics or botanicals, are natural bioactive compounds that are derived from plants and incorporated into animal feed to enhance productivity (Windisch et al., 2008). A wide range of plants and their products fall under this category and, based on their origin (part of the plant), they can be broadly classified as herbs (flowering, non-woody, non-persistent plants from which leaves and flowers are used) or spices (non-leaf parts of plants, including seeds, fruits, bark or root with intensive taste or smell) (Windisch et al., 2008; Van Der Klis and Vinyeta-Punti, 2014). They can be used in solid, dried, and ground form or as extracts (crude or concentrated). Depending on the process used to derive the active ingredients, PFA can also be classified as essential oils (EOs; volatile lipophilic substances obtained by cold extraction or by steam or alcohol distillation) and oleoresins (extracts derived by non-aqueous solvents) (Windisch et al., 2008; Van Der Klis and Vinyeta-Punti, 2014). The main bioactive compounds of the PFAs are polyphenols and their composition and concentration vary according to the plant, parts of the plant, geographical origin, harvesting season, environmental factors, storage conditions, and processing techniques (Windisch et al., 2008; Applegate et al., 2010).

In recent years, PFAs have been used as natural growth promoters in the pig and poultry industries (Windisch et al., 2008; Franz et al., 2010). A wide variety of herbs and spices (e.g., thyme, oregano, rosemary, marjoram, yarrow, garlic, ginger, green tea, black cumin, coriander, and cinnamon) have been used in poultry for their potential application as AGP alternatives. Guo et al. (2004) showed a significant increase in body weight gain and improvement in feed efficiency when broilers were given diets supplemented with a mixture of 14 herbs. Similar results were shown with the addition of oregano (Florou-Paneri et al., 2006), dried ground leaves of stevia (Atteh et al., 2008), black cumin seeds (Khalaji et al., 2011), fermented Ginkgo biloba leaves (Cao et al., 2012), and dried and ground Scrophularia striata and Ferulago angulata (Rostami et al., 2015) to poultry feed. Various plant extracts used as PFAs were also shown to improve the performance of broilers. Research trials conducted with the inclusion of sugar cane extract (El-Abasy et al., 2002), aniseed extract (Durrani et al., 2007), chestnut wood extract (Schiavone et al., 2008), Forsythia suspensa extract (Wang et al., 2008), and Portulaca oleracea extract (Zhao et al., 2013b) showed a significant increase in body weight gain and a lower FCR. In contrast, several other PFAs such as grape pomace, cranberry fruit extract, Macleaya cordata extract, garlic powder, grape seed extract, and yucca extract tested as growth promoters did not show any effects on performance parameters (Goñi et al., 2007; Brenes et al., 2008; Leusink et al., 2010; Juskiewicz et al., 2011; Viveros et al., 2011; Issa and Omar, 2012; Chamorro et al., 2013).

In addition to herbs and spices, various EOs (thymol; carvacrol; cinnamaldehyde; EOs from clove, coriander, star anise, ginger, garlic, rosemary, turmeric, basil, caraway, lemon, and sage) have been used either individually or as blends to improve animal health and performance. Variable results have been reported with the use of EOs in poultry diets. Including a blend of thymol and cinnamaldehyde in feed which was shown to improve body weight gain in broilers (Tiihonen et al., 2010; Amerah et al., 2011). Similar results were shown when supplementing diets with EO from oregano (Malayoğlu et al., 2010; Hashemipour et al., 2013, 2014) and coriander (Ghazanfari et al., 2015), blends of clove and cinnamaldehyde 
(Chalghoumi et al., 2013), thymol and EO from star anise (Kim et al., 2016a), and an herbal EO mix (Alçiçek et al., 2004; Khattak et al., 2014). EO supplementation was also shown to improve feed efficiency as seen by reduced FCRs (Çabuk et al., 2006; Isabel and Santos, 2009; Amad et al., 2011; Kim et al., 2016a). In contrast, several other trials did not show any beneficial effects of including EO on performance (Lee et al., 2003; Basmacioğlu et al., 2004; Hernández et al., 2004; Zhang et al., 2005; Jang et al., 2007). The variations in the results could be attributed to the differences in the composition, type, and origin of the EO that were used, inclusion level, and the environmental conditions of the trials (Franz et al., 2010). Nevertheless, one commercial blend of phytonutrients (containing carvacrol, cinnamaldehyde, and capsicum oleoresin) was approved in the EU as the first botanical feed additive for improving performance in broilers. Several research trials performed with this commercial blend demonstrated consistent improvement in growth and feed efficiency (Bravo et al., 2014; Karadas et al., 2014; Pirgozliev et al., 2015). A meta-analysis of 13 broiler studies involving the use of this commercial blend showed that its inclusion in diets increased body weight gain and decreased FCR and mortality (Bravo and Ionescu, 2008).

The mechanism of action of PFAs is not clearly understood and depends greatly upon the composition of the active ingredients in the product being used. In general, the beneficial effects of PFAs are attributed to their antimicrobial and antioxidant properties. The inclusion of PFAs in the diets was shown to alter and stabilize intestinal microflora and reduce microbial toxic metabolites in the gut owing to their direct antimicrobial properties on various pathogenic bacteria, which results in relief from intestinal challenge and immune stress, thus improving performance (Tiihonen et al., 2010; Viveros et al., 2011; Zhang et al., 2013; Zhao et al., 2013b; Liu et al., 2014). Another important beneficial effect of dietary inclusion of PFAs is reduction in oxidative stress and increase in antioxidant activity in various tissues and thus improved health (Basmacioğlu et al., 2004; Brenes et al., 2008; Wang et al., 2008; Cao et al., 2012; Mueller et al., 2012; Zhang et al., 2013; Liu et al., 2014; Settle et al., 2014). PFAs also exert their action through immunomodulatory effects such as increased proliferation of immune cells, elevated expression of cytokines, and increased antibody titers (Kim et al., 2010; Lee et al., 2010b; Park et al., 2011; Pourhossein et al., 2015). The addition of PFAs to the diet was also shown to increase intestinal and pancreatic enzyme production and activity and increase bile flow (Lee et al., 2003; Jang et al., 2007; Malayoğlu et al., 2010; Hashemipour et al., 2013, 2014). PFAs also help maintain and improve gut histology, increase villi height and thus expand absorptive surface of the intestine (Ghazanfari et al., 2015; Murugesan et al., 2015). Increase in digestive enzyme secretion and absorption results in improved apparent nutrient digestibility and thus improves performance Jamroz et al., 2003; Hernández et al., 2004; Jørgensen et al., 2008; Wang et al., 2008; Amad et al., 2011; Amerah et al., 2011; Issa and Omar, 2012). They also might play a role in maintaining the intestinal barrier function as evidenced by the increase in the transepithelial electrical resistance of duodenal mucosa of broilers that included thymol in their diets (Placha et al., 2014).
A growing body of scientific evidence has demonstrated that many of the health-promoting activities of phytochemicals are also mediated through their ability to enhance the host's defense against microbial infections and tumors (Lillehoj et al., 2011). The immune-activating properties of medicinal plants such as dandelion (Taraxacum officinale), mustard (Brassica juncea), and safflower (Carthamus tinctorius) have been evaluated in vitro using avian lymphocytes and macrophages (Lee et al., 2007). All three extracts inhibited tumor cell growth and exhibited antioxidant effects. Further, the safflower extract stimulated chicken lymphocyte proliferation, whereas the mustard extract induced nitric oxide production by macrophages. In a separate study, organic phase extracts from milk thistle (Silybum marianum), turmeric (Curcuma longa), reishi mushroom (Ganoderma lucidum), and shiitake mushroom (Lentinus edodes) were tested for their effects on chicken innate immunity and tumor cell cytotoxicity (Lee et al., 2010a). In chicken macrophages treated with extracts of turmeric (Curcuma longa) or shiitake mushroom (Lentinus edodes) in vitro (Lee et al., 2010b), the levels of gene transcripts for IL-1 $\beta$, IL-6, IL-12, IL-18, and TNFSF15 were increased. The phagocytic activity of chicken heterophils was shown to be significantly improved with the addition of non-dialyzable materials of cranberry extract at $4 \mathrm{mg} \mathrm{ml}^{-1}$ concentration (Islam et al., 2016). Cinnamaldehyde ((2E)-3-phenylprop-2-enal) is a constituent of cinnamon (Cinnamomum cassia), a widely used flavoring compound that has been traditionally used to treat human diseases, including dyspepsia, gastritis, and inflammation. Chicken spleen lymphocytes that were stimulated in vitro with cinnamaldehyde showed good cell proliferation, and cinnamaldehyde activated cultured macrophages to produce higher nitric oxide levels (Lee et al., 2011b). The effects of carvacrol, cinnamaldehyde, and Capsicum oleoresin on the regulation of the expression of genes associated with immunology, physiology, and metabolism were investigated in chickens using highthroughput microarray analysis (Lillehoj et al., 2011). These studies revealed that Capsicum oleoresin stimulated a great number of gene changes when compared with unsupplemented controls, and many of the altered genes were associated with metabolism and immunity. The most reliable genetic network induced by dietary cinnamaldehyde treatment was related to the functions of antigen presentation, humoral immunity, and inflammatory disease. Further studies to delineate the intestinal immune pathways affected by phytochemical feeding were conducted by mRNA microarray hybridization (Kim et al., 2010). When compared with chickens fed an unsupplemented diet, carvacrol-fed chickens showed altered levels of 74 gene transcripts in gut lymphocytes (26 increased, 48 decreased), cinnamaldehyde supplementation was associated with altered levels of 62 mRNAs (31 increased, 31 decreased), and Capsicum oleoresin-fed chickens had altered levels of 254 mRNAs (98 increased, 156 decreased), compared with unsupplemented controls. Among the transcripts that showed greater than twofold altered expression levels, most were encoded by genes associated with metabolic pathways. In the case of Capsicum oleoresin, the transcripts included pathways for lipid metabolism, small molecule biochemistry, and cancer. In another investigation, global gene expression analysis by microarray hybridization identified 
1810 transcripts (677 increased, 1133 decreased) whose levels were significantly altered in intestinal lymphocytes of anethole-fed birds when compared with unsupplemented controls (Kim et al., 2013a). From these, 576 corresponding genes were identified that were related to the inflammatory response. A similar analysis was reported for the garlic metabolites, propyl thiosulphinate PTS) and PTS oxide (PTSO) (Kim et al., 2013b). In that study, 1227 transcripts (552 increased, 675 decreased) were identified in intestinal lymphocytes whose levels were significantly altered in PTS/PTSO-fed birds when compared with unsupplemented controls. Many of these transcripts were encoded by genes related to innate immunity, including

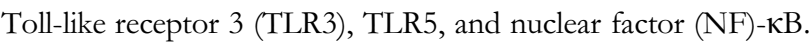

\section{Hyperimmune egg yolk antibodies}

Hyperimmune egg yolk antibodies ( $\operatorname{IgY}$ ), produced by repeated immunization of hens with specific antigens and collection of antibodies thereafter from their egg yolks, have been commonly employed in the prevention and treatment of various enteric diseases in humans and animals (Gadde et al., 2015). Limited research exists on the use of egg yolk antibodies as viable alternatives to AGP in improving growth and feed efficiency in poultry (Cook, 2004). Earlier studies were focused on generation of egg antibodies in breeding hens that could be passively transferred to the progeny and improve their productivity. Pimentel and Cook (1988) and Pimentel et al. (1991) showed that progeny from hens injected with jack bean urease had improved body weight at 3 weeks of age. It was proposed that urease antibodies maternally transferred to the progeny decreased ammonia production in the intestinal tract by inhibiting bacterial urease enzyme and improving growth. As IgY technology evolved, research trials conducted later on involved the use of antibodies in feed to improve performance or enhance host immunity (Lee et al., 2009a, b). The majority of these studies encompassed the use of antibodies that were raised against components involved in the immune regulation of growth. The growth suppression associated with immune stimulation is well established, and it is hypothesized that interleukin 1 (IL-1) released during inflammation causes anorexia (through the release of neuropeptides like cholecystokinin (CCK), neuropeptide $\mathrm{Y}$ into gut lumen) and muscle wasting (Goldberg et al., 1984; Klasing et al., 1987). Cook (2004) reported that hyperimmune egg yolk antibodies raised against various neuropeptides (CCK, neuropeptide Y) improved body weight and feed efficiency when fed to broiler chickens up to 3 weeks of age. They showed that supplementing diets with egg powder containing CCK antibodies at $0.25 \mathrm{~g} \mathrm{~kg}^{-1}$ dose improved the feed conversion efficiency by 13 points compared with that of birds fed egg powder from unimmunized hens. Similar results were shown in a series of trials in which chicks were fed dried egg yolk powder from hens vaccinated with neuropeptide $\mathrm{Y}$ or from control unimmunized hens. The average improvement in weight gain and FCR at 3 weeks of age was shown to be $9 \%$ and 8 points, respectively, compared with controls (Cook, 2004). Eicosanoids are also believed to play a proinflammatory role in immune stimulation, and supplementing feed with egg antibodies $\left(\mathrm{BIG}^{\mathrm{TM}}\right)$ developed against phospholipase A2 (an enzyme involved in eicosanoid synthesis) for 3 weeks improved the mean weight gain of broilers by $5.4 \%$ and the FCR by 6.2 points (Cook, 2001, 2002).

The use of egg yolk antibodies offers several advantages. Large quantities of antibodies can be produced in laying hens and non-invasively collected. Their use is environmentally friendly, less toxic and does not select for resistance. Although the existing results seemed encouraging, much more research is needed on using egg antibodies for growth promotion in poultry.

\section{Antimicrobial peptides}

AMPs are widely distributed, small, gene-encoded peptides that have germicidal properties. They have been seen in all kingdoms of life and have shown activity against a wide range of pathogens such as Gram-negative and Gram-positive bacteria, fungi, enveloped viruses, and parasites (Koczulla and Bals, 2003; Li et al., 2012; Kim et al., 2016b). Mature AMPs generally contain 12 100 amino acids, are rich in hydrophobic cationic residues, and have an amphipathic structure that facilitates interaction with negatively charged membranes of microbials as well as other cellular targets (Yeaman and Yount, 2007; Linde et al., 2008; Wang et al., 2014). To date, over 2600 endogenous AMPs have been isolated and many more synthetic analogues were reported in various publications (http://aps.unmc.edu/AP/main.php; Fosgerau and Hoffmann, 2015). The studies that have been done on AMPs and their applications in poultry have been mostly focused on their protective potential against diverse pathogens causing infectious diseases rather than growthpromoting activities. However, a few research trials investigating the effect of AMPs on poultry growth performance, intestinal morphology, and gut microbiology as potential AGP alternatives have been explored. One such trial demonstrated that supplementing with yeast-expressed cecropin A (1-11)-D(12-37)-Asn $(\mathrm{CADN})$, a chimeric peptide derived from insects, in poultry diets increased weight gain, feed intake, feed:gain ratio, and intestinal villus height while decreasing aerobic bacterial counts in both jejunal and cecal digests (Wen and He, 2012). In consistency with the previous result, Choi et al. (2013) reported the beneficial effects of diets supplemented with a chemically synthesized AMP-P5, analog of hybrid AMP cecropin A (1-8)-magainin 2(1-12) (CAMA), on chicken performance, nutrient retention, intestinal morphology, as well as excreta and intestinal microflora. One Chinese research group investigated the effects of naturally synthesized AMPs obtained from swine and rabbit. The AMPs were extracted from swine gut and rabbit sacculus rotundus, respectively, and were orally inoculated or supplemented in water or diets. They reported that the birds that were given naturally synthesized AMPs showed improvement in growth performance, intestinal ability to absorb nutrients and mucosal immune parameters such as intraepithelial lymphocytes or mast cell counts, and in secretory IgA levels when compared with unsupplemented or non-inoculated birds (Liu et al., 2008; Bao et al., 2009; Wang et al., 2009). 
Based on the origins of AMPs, there is a particular group of AMPs called bacteriocins. Bacteriocins are defined as ribosomally synthesized peptides that are secreted by various bacteria that have antibacterial activity against other similar or closely related bacteria. In the past, bacteriocins were mostly used as food preservatives and were believed to be produced only by specific bacterial strains (Cleveland et al., 2001). Thus, its production had been considered an important feature in the selection of probiotic strains, but now one or more bacteriocins have been identified and believed to exist in all species of bacteria and archaea (Cotter et al., 2005; Willey and van der Donk, 2007). Currently, 177 bacteriocins have been identified in 31 genera, including Gram-positive and Gram-negative bacteria as well as archaea (http://bactibase.pfba-lab-tun.org/main.php). They are mainly cationic, hydrophobic, or amphiphilic like other AMPs (Riley and Wertz, 2002). Generally, they have been shown to possess a relatively narrow spectrum of antimicrobial activity when compared with AMPs produced by non-bacterial origin. One of the most reported bacteriocins as a dietary supplement in poultry is divercin AS7, which is produced by Carnobacterium divergens AS7, a lactic acid-producing bacterium isolated from fish, which has been extensively studied by Józefiak and colleagues. The authors have focused on the application of divercin AS7 to improve growth performance, nutrient retention, intestinal histomorphology, and balance of gastrointestinal microbiota. They demonstrated that supplementing broiler diets with divercin AS7 has an in vivo growth-promoting effect, increasing digestibility as well as a modulatory effect on intestinal microbiota (Józefiak et al., 2010, 2011a, b, 2012). Supplementation of divercin AS7 reduced intestinal digesta $\mathrm{pH}$ in a series of their studies, which reflected the activity of the gastrointestinal microbiota and digestion physiology (Engberg et al., 2002). In addition, dietary nisin, which is produced by Lactococcus lactis and is the sole bacteriocin approved for use as a food additive by the FDA, exerted a modulatory effect on the microbial ecology of the gastrointestinal tract with decreased counts of Bacteroides and Enterobacteriacae, but unchanged counts of Clostridium perfringens, Lactobacillus spp., Enterococcus spp., and total bacteria (Józefiak et al., 2013). Albusin B, which is another bacteriocin that is produced by Ruminococcus albus 7, was added to poultry feed and also showed improved growth performance, increased intestinal absorption and Lactobacillus counts, modulated lipid metabolism, and activated systemic antioxidant defense (Wang et al., 2011, 2013a).

Despite the fact that limited research exists on the use of AMPs as alternatives to AGP, collectively dietary supplementation of AMPs in poultry seems to affect the birds in a positive way by improving their intestinal balance and creating gut microecological conditions that suppress harmful microorganisms like Clostridium spp. and coliforms while favoring beneficial microorganisms like Lactobacillus spp. (Ohh et al., 2009). In conclusion, the AMPs including bacteriocins have the potential to considerably enhance poultry health as alternatives to AGP and their potential might be improved when a number of obstacles such as high production cost, resistance development, and instability of the AMPs are addressed in the future.

\section{Bacteriophages}

Bacteriophages, which were discovered in the early 1900s (Twort, 1915; d'Herelle, 1917), are highly species-specific viruses that kill bacteria through the production of endolysins and the subsequent lysis of the bacterial cells (Joerger, 2003; Huff et al., 2005). Bacteriophages can be considered safe antibiotic alternatives as they exhibit no activity against animal and plant cells. They have been used to prevent and treat various bacterial diseases in humans and animals (Huff et al., 2003; Miller et al., 2010). A significant amount of research was also done on their use in control of food-borne pathogens on agricultural and poultry products (Goode et al., 2003; Huff et al., 2004). Very few studies demonstrated the effects of supplementing diets with bacteriophages on growth performance. Zhao et al. (2012) evaluated the effects in laying hens and reported that incorporating 0.035 or $0.05 \%$ of bacteriophages in their diet significantly improved egg production. Increased body weight gain and reduced FCR were reported in broilers given diets supplemented with 0.10 and $0.15 \%$ (Kim et al., 2013c) or $0.5 \mathrm{~g} \mathrm{~kg}^{-1}$ of bacteriophages, respectively (Wang et al., 2013b). However, further research is needed to establish the performance effects of bacteriophages and make their use practical in poultry production systems.

\section{Clay}

Clay minerals (also designated as phyllosilicates) are formed by a net of stratified tetrahedral and octahedral layers containing molecules of silicon, aluminum, and oxygen, and interconnected by hydrogen bonds or a group of cations (Vondruskova et al., 2010). The natural extracted clays (bentonite, zeolite, kaolin, etc.) are a mixture of various clay minerals that differ in chemical composition (Vondruskova et al., 2010). Clay minerals, because of their stratified structure, have great adsorption capacity and can bind aflatoxins, plant metabolites, heavy metals, enterotoxins, and pathogens. The factors affecting the extent of adsorption include the chemistry of the clay minerals, the fine structure of the clay particles, and their surface properties, $\mathrm{pH}$, dosage, and exposure time (Thacker, 2013). Many research trials were conducted to show the antibacterial and detoxifying effects of clay in poultry (Kubena et al., 1998; Phillips, 1999; Fowler et al., 2015), but very few trials investigated their growthpromoting effects. Xia et al. (2004) reported that including copper-bearing montmorillonite in broiler diets significantly improved growth performance, reduced Escherichia coli and Clostridium spp. counts in the intestine, and increased intestinal digestive enzyme activity. Dietary inclusion of hydrated aluminosilicate $\left(5 \mathrm{~g} \mathrm{~kg}^{-1}\right)$ significantly increased body weight gain of broilers at 1 and 3 weeks of age and increased serum amylase and lactate dehydrogenase activity (Prvulović et al., 2008). Similar improvement results in performance were shown upon supplementing diets with kaolin, bentonite, zeolite (Katouli et al., 2010), clay (Ani et al., 2014), and kaolin (Jorge de Lemos et al., 2015). Wu et al. (2013) showed that adding clinoptilolite to diets improved antioxidant capacity in broilers as evidenced by increased glutathione peroxidase, catalase, and total 
superoxide dismutase activities and decreased malondialdehyde content of liver. However, results of including clay minerals appeared to be inconsistent, as some research trials showed no effect on performance (Wu et al., 2013).

The mechanism by which clays and clay minerals influence growth is unclear, but it depends largely on their ability to physically bind and remove toxins, anti-nutritional components, and pathogenic organisms. This results in reducing microbial metabolites, toxins, and enzymes in the intestine and thus preventing irritation and damage and improving morphological characteristics of the intestinal mucosa (Xia et al., 2004; Jorge de Lemos et al., 2015) and thus performance. The inclusion of clay was also shown to improve nutrient digestibility by reducing digest transit time and also decreasing litter moisture (Olver, 1997; Jorge de Lemos et al., 2015). Further research should be done on the role of clay as a potential alternative to AGP and its effects when combined with other products.

\section{Metals}

Heavy metals such as copper, zinc, iron, selenium and manganese, often referred as trace minerals in animal nutrition, are extensively used in food animal production to maintain general health and normal physiology (Scott, 2012). They play a vital role in growth and metabolism as they are critical for many digestive, physiological, and biosynthetic processes (Richards et al., 2010; Attia et al., 2012). Traditionally, heavy metals have been supplemented in animal diets in the form of inorganic salts such as carbonates, chlorides, oxides, and sulfates (Pierce et al., 2009; Attia et al., 2012), but chelated or organic forms have also been used lately. The use of trace minerals to increase animal productivity and performance has been gaining importance in the recent years and they are being substituted in levels beyond the recommended nutritional requirements. Copper, an essential trace mineral, plays a significant role in hemoglobin synthesis, angiogenesis, connective tissue, bone development, and more importantly serves as a cofactor for many metabolic enzymes (Brainer et al., 2003; Richards et al., 2010; Vasanth et al., 2015). The use of copper as growth promotant in poultry diets has been well demonstrated. Supplementation of diets with copper sulfate, citrate, or carbonate at levels ranging from 125 to $250 \mathrm{mg} \mathrm{Cu} \mathrm{kg}^{-1}$ showed improvement in body weight and feed efficiency (Hoda and Maha, 1995; Pesti and Bakalli, 1996). Ewing et al. (1998) demonstrated that addition of cupric sulfate pentahydrate and copper oxychloride to the broiler diets increased weight gain by $4.9 \%$ and cupric citrate increased weight gain by $9.1 \%$ compared with non-supplemented controls. In-feed supplementation of tribasic copper chloride or copper sulfate was also shown to significantly increase average daily gain and carcass weight in broilers (Arias and Koutsos, 2006; $\mathrm{Lu}$ et al., 2010). Zinc is another important essential trace mineral that has been used to improve performance in poultry. Zinc serves as a cofactor for several cellular enzymes and transcription factors and plays an essential role in cell proliferation, immune response, reproduction, gene regulation, and defense against oxidative stress and damage (Richards et al., 2010). Supplementation of zinc sulfate up to $80 \mathrm{mg} \mathrm{kg}^{-1}$ in the basal diets was shown to significantly improve body weight gain of broilers but no differences in mortality and feed efficiency were observed (Burrell et al., 2004). Similar improvements in performance were shown when broilers were given diets with zinc oxide along with sodium selenite for 4 weeks (Fawzy et al., 2016). In contrast to these studies, several other research trials investigating the beneficial effects of zinc supplementation did not show any performance effects, but in general observed improved immune status of the birds (Sunder et al., 2008; Yogesh et al., 2013). The growth promotant effect seen following in-feed supplementation of some of the metals such as zinc, copper can be attributed to their antimicrobial properties (Cromwell, 1991; Brainer et al., 2003; Yazdankhah et al., 2014). From studies conducted in pigs, it was proposed that zinc and copper alter the intestinal microbiota by reducing the levels of both commensal and pathogenic bacteria, and also by reducing fermentation loss of nutrients (Højberg et al., 2005; Yazdankhah et al., 2014). Use of metals as growth promotants should be adapted with caution as they may come with some disadvantages. Inclusion of metals in excess amounts raises environmental concerns in terms of their accumulation in soil and surface water (Burrell et al., 2004). Also, excess use of metals has been shown to develop metal resistance with concomitant crossresistance to antibiotics among enteric bacteria in farm animals (Yazdankhah et al., 2014).

\section{Conclusions}

Owing to the rise in consumer demand for livestock products from antibiotic-free production systems, there exists a great need for the development of antibiotic alternatives that can help improve performance and maintain optimal health of food animals. Several products have been evaluated in poultry over the past several years for their potential to replace antibiotics. Though the beneficial effects of many of the alternatives tested have been well demonstrated, there is the general consensus that these products lack consistency, as results vary greatly from farm to farm. Care must be taken in the choice of alternatives, such that they fit the needs of the individual production program. Further research is needed regarding understanding their mechanism of action, identifying means to standardize the effects, improving delivery methods (e.g. microencapsulation) for site-targeted delivery, and increasing their in vivo efficacy. Combinations of products may prove more beneficial than using them alone to achieve an effect similar to that of antibiotics. Using optimal combinations of various alternatives coupled with good management and husbandry practices will be the key to maximizing performance and maintaining animal productivity, while we move forward with the ultimate goal of reducing antibiotic use in the animal industry.

\section{Acknowledgment}

This project was supported by ARS-USDA CRIS in Animal Health (NP103) \# 8042-32000-107-00D. 


\section{References}

Adeola O and Cowieson AJ (2011). Opportunities and challenges in using exogenous enzymes to improve non-ruminant animal production. Journal of Animal Science 89: 3189-3218.

Adil S, Banday T, Bhat GA, Mir MS and Rehman M (2010). Effect of dietary supplementation of organic acids on performance, intestinal histomorphology, and serum biochemistry of broiler chicken. Veterinary Medicine International 2010: 479485.

Adil S, Banday T, Bhat GA, Salahuddin M, Raquib M and Shanaz S (2011). Response of broiler chicken to dietary supplementation of organic acids. Journal of Central European Agriculture 12: 498-508.

Ahmed ST, Islam MM, Mun HS, Sim HJ, Kim YJ and Yang CJ (2014). Effects of Bacillus amyloliquefaciens as a probiotic strain on growth performance, cecal microflora, and fecal noxious gas emissions of broiler chickens. Poultry Science 93: 1963-1971.

Alçiçek A, Bozkurt M and Çabuk M (2004). The effect of a mixture of herbal essential oils, an organic acid or a probiotic on broiler performance. South African Journal of Animal Science 34: 217-222.

Alimohamadi K, Taherpour K, Ghasemi HA and Fatahnia F (2014). Comparative effects of using black seed (Nigella sativa), cumin seed (Cuminum cyminum), probiotic or prebiotic on growth performance, blood hematology and serum biochemistry of broiler chicks. Journal of Animal Physiology and Animal Nutrition 98: 538546.

Alzueta C, Rodríguez ML, Ortiz LT, Rebolé A and Treviño J (2010). Effects of inulin on growth performance, nutrient digestibility and metabolisable energy in broiler chickens. British Poultry Science 51: 393-398.

Alloui MN, Szczurek W and Świątkiewicz S (2013). The usefulness of prebiotics and probiotics in modern poultry nutrition: a review. Annals of Animal Science 13: 17-32.

Amad AA, Männer K, Wendler KR, Neumann K and Zentek J (2011). Effects of a phytogenic feed additive on growth performance and ileal nutrient digestibility in broiler chickens. Poultry Science 90: 2811-2816.

Amerah AM, Péron A, Zaefarian F and Ravindran V (2011). Influence of whole wheat inclusion and a blend of essential oils on the performance, nutrient utilisation, digestive tract development and ileal microbiota profile of broiler chickens. British Poultry Science 52: 124-132.

Ani AO, Ogbu CC and Iloh EA (2014). Response of broiler chicks to diets containing graded levels of clay. Journal of Animal and Plant Sciences 24: 30-34.

Apata DF (2008). Growth performance, nutrient digestibility and immune response of broiler chicks fed diets supplemented with a culture of Lactobacillus bulgaricus. Journal of the Science of Food and Agriculture 88: 1253-1258.

Applegate TJ, Klose V, Steiner T, Ganner A and Schatzmayr G (2010). Probiotics and phytogenics for poultry: myth or reality? Journal of Applied Poultry Research 19: 194-210.

Arias VJ and Koutsos EA (2006). Effects of copper source and level on intestinal physiology and growth of broiler chickens. Poultry Science 85: 999-1007.

Ashayerizadeh A, Dabiri N, Ashayerizadeh O, Mirzadeh KH, Roshanfekr H and Mamooee M (2009). Effect of dietary antibiotic, probiotic and prebiotic as growth promoters, on growth performance, carcass characteristics and hematological indices of broiler chickens. Pakistan Journal of Biological Sciences 12: 52-57.

Attia YA, Qota EM, Zeweil HS, Bovera F, Abd Al-Hamid AE and Sahledom MD (2012). Effect of different dietary concentrations of inorganic and organic copper on growth performance and lipid metabolism of White Pekin male ducks. British Poultry Science 53: 77-88.

Atteh JO, Onagbesan OM, Tona K, Decuypere E, Geuns JMC and Buyse J (2008). Evaluation of supplementary stevia (Stevia rebaudiana, bertomi) leaves and stevioside in broiler diets: effects on feed intake, nutrient metabolism, blood parameters and growth performance. Journal of Animal Physiology and Animal Nutrition 92 : 640-649.

Awad WA, Ghareeb K, Abdel-Raheem S and Böhm J (2009). Effects of dietary inclusion of probiotic and synbiotic on growth performance, organ weights, and intestinal histomorphology of broiler chickens. Poultry Science 88: 49-55.

Bai SP, Wu AM, Ding XM, Lei Y, Bai J, Zhang KY and Chio JS (2013). Effects of probiotic-supplemented diets on growth performance and intestinal immune characteristics of broiler chickens. Poultry Science 92: 663-670.

Banday MT, Adil S, Khan AA and Untoo M (2015). A study of efficacy of fumaric acid supplementation in diet of broiler chicken. International Journal of Poultry Science 14: 589-594.

Bao H, She R, Liu T, Zhang Y, Peng KS, Luo D, Yue Z, Ding Y, Hu Y, Liu W and Zhai L (2009). Effects of pig antibacterial peptides on growth performance and intestine mucosal immune of broiler chickens. Poultry Science 88: 291-297.

Basmacioğlu H, Tokuşoğlu Ö and Ergül M (2004). The effect of oregano and rosemary essential oils or alpha-tocopheryl acetate on performance and lipid oxidation of meat enriched with n-3 PUFA's in broilers. South African Journal of Animal Science 34: 197-210.

Baurhoo B, Phillip L and Ruiz-Feria CA (2007). Effects of purified lignin and mannan oligosaccharides on intestinal integrity and microbial populations in the ceca and litter of broiler chickens. Poultry Science 86: 1070-1078.

Bedford M (2000). Removal of antibiotic growth promoters from poultry diets: implications and strategies to minimise subsequent problems. World's Poultry Science Journal 56: 347-365.

Bedford MR and Cowieson AJ (2012). Exogenous enzymes and their effects on intestinal microbiology. Animal Feed Science and Technology 173: 76-85.

Bedford MR and Schulze H (1998). Exogenous enzymes for pigs and poultry. Nutrition Research Reviews 11: 91-114.

Benites V, Gilharry R, Gernat AG and Murillo JG (2008). Effect of dietary mannan oligosaccharide from Bio-Mos or SAF-Mannan on live performance of broiler chickens. Journal of Applied Poultry Research 17: 471-475.

Biggs P and Parsons CM (2008). The effects of several organic acids on growth performance, nutrient digestibilities, and cecal microbial populations in young chicks. Poultry Science 87: 2581-2589.

Blajman JE, Frizzo LS, Zbrun MV, Astesana DM, Fusari ML, Soto LP, Rosmini MR and Signorini ML (2014). Probiotics and broiler growth performance: a meta-analysis of randomized controlled trials. British Poultry Science 55: 483-494.

Boroojeni F, Vahjen W, Mader A, Knorr F, Ruhnke I, Röhe I, Hafeez A, Villodre C, Männer K and Zentek J (2014). The effects of different thermal treatments and organic acid levels in feed on microbial composition and activity in gastrointestinal tract of broilers. Poultry Science 93: 1440-1452.

Bozkurt M, Küçükyilmaz K, Çatli AU and Çinar M (2008). Growth performance and slaughter characteristics of broiler chickens fed with antibiotic, mannan oligosaccharide and dextran oligosaccharide supplemented diets. International Journal of Poultry Science 7: 969-977.

Brainer MMA, Menten JFM, Vale MM and Morais SCD (2003). Cupric citrate as growth promoter for broiler chickens in different rearing stages. Scientia Agricola 60: 441-445.

Bravo D and Ionescu C (2008). Meta-analysis of the effect of a mixture of carvacrol, cinnamaldehyde and capsicum oleoresin in broilers. Poultry Science 87 (suppl. 1): 75.

Bravo D, Pirgozliev V and Rose SP (2014). A mixture of carvacrol, cinnamaldehyde, and capsicum oleoresin improves energy utilization and growth performance of broiler chickens fed maize-based diet. Journal of Animal Science 92: 1531-1536.

Brenes A, Viveros A, Goñi I, Centeno C, Sáyago-Ayerdy SG, Arija I and Saura-Calixto F (2008). Effect of grape pomace concentrate and vitamin $\mathrm{E}$ on digestibility of polyphenols and antioxidant activity in chickens. Poultry Science 87: 307-316. 
Brennan KM, Graugnard DE, Xiao R, Spry ML, Pierce JL, Lumpkins B and Mathis GF (2013). Comparison of gene expression profiles of the jejunum of broilers supplemented with a yeast cell wall-derived mannan oligosaccharide versus bacitracin methylene disalicylate. British Poultry Science 54: 238-246.

Brown M (2011). Modes of action of probiotics: recent developments. Journal of Animal and Veterinary Advances 10: 1895-1900.

Burrell AL, Dozier WA III, Davis AJ, Compton MM, Freeman ME, Vendrell PF and Ward TL (2004). Responses of broilers to dietary zinc concentrations and sources in relation to environmental implications. British Poultry Science 45: 255-263.

Çabuk M, Bozkurt M, Alçiçek A, Akbaş Y and Küçükyilmaz K (2006). Effect of a herbal essential oil mixture on growth and internal organ weight of broilers from young and old breeder flocks. South African Journal of Animal Science 36: 135-141.

Cao FL, Zhang XH, Yu WW, Zhao LG and Wang T (2012). Effect of feeding fermented Ginkgo biloba leaves on growth performance, meat quality, and lipid metabolism in broilers. Poultry Science 91: 1210-1221.

Calik A and Ergün A (2015). Effect of lactulose supplementation on growth performance, intestinal histomorphology, cecal microbial population, and short-chain fatty acid composition of broiler chickens. Poultry Science 94: 2173-2182.

Castanon JIR (2007). History of the use of antibiotic as growth promoters in European poultry feeds. Poultry Science 86: 2466-2471.

Cavazzoni V, Adami A and Castrovilli C (1998). Performance of broiler chickens supplemented with Bacillus coagulans as probiotic. British Poultry Science 39: 526-529.

Chalghoumi R, Belgacem A, Trabelsi I, Bouatour Y and Bergaoui R (2013). Effect of dietary supplementation with probiotic or essential oils on growth performance of broiler chickens. International Journal of Poultry Science 12: 538-544.

Chamorro S, Viveros A, Centeno C, Romero C, Arija I and Brenes A (2013). Effects of dietary grape seed extract on growth performance, amino acid digestibility and plasma lipids and mineral content in broiler chicks. Animal 7: 555-561.

Cheng G, Hao H, Xie S, Wang X, dai M, Huang L and Yuan Z (2014). Antibiotic alternatives: the substitution of antibiotics in animal husbandry? Frontiers in Microbiology 5: 217.

Chiang SH and Hsieh WM (1995). Effect of direct fed microorganisms on broiler growth performance and litter ammonia level. Asian-Australasian Journal of Animal Sciences 8: 159-162.

Chichlowski J, Croom J, McBride BW, Havenstein GB and Koci MD (2007). Metabolic and physiological impact of probioitcs or Direct-Fed-Microbials on poultry: a brief review of current knowledge. International Journal of Poultry Science 6: 694-704.

Cho JH and Kim IH (2014). Effects of lactulose supplementation on performance, blood profiles, excreta microbial shedding of Lactobacillus and Eschericbia coli, relative organ weight and excreta noxious gas contents in broilers. Journal of Animal Physiology and Animal Nutrition 98: 424-430.

Cho I, Yamanishi S, Cox L, Methé BA, Zavadil J, Li K, Gao Z, Mahana D, Raju K, Teitler I, Li H, Alekseyenko AV and Blaser MJ (2012). Antibiotics in early life alter the murine colonic microbiome and adiposity. Nature 488: 621-626.

Choct M (2001). Alternatives to in-feed antibiotics in monogastric animal industry. American Soybean Association Technical Bulletin 30: 1-6.

Choct M (2006). Enzymes for the feed industry: past, present and future. Worlds's Poultry Science Journal 62: 5-15.

Choct M (2009). Managing gut health through nutrition. British Poultry Science 50: 9-15.

Choi SC, Ingale SL, Kim JS, Park YK, Kwon IK and Chae BJ (2013). An antimicrobial peptide-A3: effects on growth performance, nutrient retention, intestinal and faecal microflora and intestinal morphology of broilers. British Poultry Science 54: 738-746.

Chowdhury R, Islam KMS, Khan MJ, Karim MR, Haque MN, Khatun $\mathrm{M}$ and Pesti GM (2009). Effect of citric acid, avilamycin, and their combination on the performance, tibia ash, and immune status of broilers. Poultry Science 88: 1616-1622.
Ciorba MA (2012). A Gastroenterologist's guide to probiotics. Clinical Gastroenterology and Hepatology 10: 960-968.

Cleveland J, Montville TJ, Nes IF and Chikindas ML (2001). Bacteriocins: safe, natural antimicrobials for food preservation. International Journal of Food Microbiology 71: 1-20.

Cook ME (2001). Method of using anti-phospholipase A2 antibodies to enhance growth or improve feed efficiency. US Patent 6,213,930 B1.

Cook ME (2002). Method of using anti-phospholipase A2 antibodies to enhance growth or improve feed efficiency. US Patent 6,383,485.

Cook ME (2004). Antibodies: alternatives to antibiotics in improving growth and feed efficiency. Journal of Applied Poultry Research 13: 106-119.

Corrigan A, Horgan K, Clipson N and Murphy RA (2011). Effect of dietary supplementation with a Saccharomyces cerevisiae mannan oligosaccharide on the bacterial community structure of broiler cecal contents. Applied and Environmental Microbiology 77: 66536662.

Cosby DE, Cox NA, Harrison MA, Wilson JL, Buhr RJ and Fedorka-Cray PJ (2015). Salmonella and antimicrobial resistance in broilers: a review. Journal of Applied Poultry Research 24: 408-426.

Cotter PD, Hill C and Ross RP (2005). Bacteriocins: developing innate immunity for food. Nature Reviews Microbiology 3: 777-788.

Cox CM and Dalloul RA (2015). Immunomodulatory role of probiotics in poultry and potential in ovo application. Beneficial Microbes 6: 45-52.

Cox LM, Yamanishi S, Sohn J, Alekseyenko AV, Leung JM, Cho I, Kim SG, Li H, Gao Z, Mahana D, Rodriguez JGZ, Rogers AB, Robine $\mathrm{N}$, Loke P and Blaser JM (2014). Altering the intestinal microbiota during a critical developmental window has lasting metabolic consequences. Cell 158: 705-721.

Cromwell GL (1991). Antimicrobial agents. In: Miller ER, Ullrey DE and Lewis AJ (eds) Swine Nutrition. Stoneham: ButterworthHeinemann, pp. 297-314.

Czerwiński J, Højberg O, Smulikowska S, Engberg RM and Mieczkowska A (2010). Influence of dietary peas and organic acids and probiotic supplementation on performance and caecal microbial ecology of broiler chickens. British Poultry Science 51: 258-269.

Dahiya JP, Wilkie DC, Van Kessel AG and Drew MD (2006). Potential strategies for controlling necrotic enteritis in broiler chickens in post-antibiotic era. Animal Feed Science and Technology 129: 60-88.

d'Herelle F (1917). Sur un microbe invisible antagonists des bacilles dysenteriques. Comptes rendus de l'Académie des Sciences 165: 373-375.

Dibner JJ and Buttin P (2002). Use of organic acids as a model to study the impact of gut microflora on nutrition and metabolism. Journal of Applied Poultry Research 11: 453-463.

Dibner JJ and Richards JD (2005). Antibiotic growth promoters in agriculture: history and mode of action. Poultry Science 84: 634-643.

Dumonceaux TJ, Hill JE, Hemmingsen SM and Van Kessel AG (2006). Characterization of intestinal microbiota and response to dietary virginiamycin supplementation in the broiler chicken. Applied and Environmental Microbiology 72: 2815-2823.

Durrani FR, Sultan A, Ahmed S, Chand N, Khattak FM and Durrani Z (2007). Efficacy of aniseed extract as immune stimulant and growth promoter in broiler chicks. Pakistan Journal of Biological Sciences 10: 3718-3721.

Edens FW (2003). An alternative for antibiotic use in poultry: probiotics. Revista Brasileria de Ciência Avicola 5: 75-97.

Endtz HP, Mouton RP, van der Reyden T, Ruijs GJ, Biever M and van Klingeren B (1990). Fluoroquinolone resistance in Campylobacter spp. isolated from human stools and poultry products. Lancet 335: 787.

Engberg RM, Hedemann MS and Jensen BB (2002). The influence of grinding and pelleting of feed on the microbial composition and activity in the digestive tract of broiler chickens. British Poultry Science 43: 569-579.

El-Abasy M, Motobu M, Shimura K, Na KJ, Kang CB, Koge K, Onodera T and Hirota Y (2002). Immunostimulating and growth- 
promoting effects of Sugar Cane Extract (SCE) in chickens. Journal of Veterinary Medical Science 64: 1061-1063.

Ewing HP, Pesti GM, Bakalli RI and Menten JFM (1998). Studies on the feeding of cupric sulfate pentahydrate, cupric citrate, and copper oxychloride to broiler chickens. Poultry Science 77: 445-448.

FAO/WHO (2001). Health and nutritional properties of probiotics in food including powder milk with live lactic acid bacteria. Report of a Joint FAO/WHO Expert Consultation on Evaluation of Health and Nutritional Properties of Probiotics in Food including Powder Mille with Live Lactic Acid Bacteria; FAO/WHO: Córdoba, Argentina, pp. 1-34.

FAO (2007). FAO technical meeting on prebiotics. [Available online at http://www.fao.org/ag/agn/files/prebiotics_tech_meeting. report.pdf.]

Faria Filho DE, Torres KAA, Faria DE, Campos DMB and Rosa PS (2006). Probiotics for broiler chickens in Brazil: systematic review and meta-analysis. Bravilian Journal of Poultry Science 8: 89-98.

Fawzy MM, El-Sadawi HA, El-Dien MH and Mohamed WAM (2016). Hematological and biochemical performance of poultry following zinc oxide and sodium selenite supplementation as food additives. Annals of Clinical Pathology 4: 1076.

FDA (2013). Guidance for Industry \#213: New animal drugs and new animal drug combination products administered in or on medicated feed or drinking water of food-producing animals: Recommendations for drug sponsors for voluntarily aligning product use conditions with GFI \#209. [Available online at http:/ / www.fda.gov/downloads/ AnimalVeterinary/GuidanceComplianceEnforcement/Guidancefor Industry/UCM299624.pdf]

Feighner SD and Dashkevicz MP (1987). Subtherapeutic levels of antibiotics in poultry feeds and their effects on weight gain, feed efficiency and bacterial cholyltaurine hydrolase activity. Applied Environmental Microbiology 53: 331-336.

Ferket PR, Santos AA Jr and Oviedo-Rondon EO (2005). Dietary factors that affect gut health and pathogen colonization. In: Proceedings of 32nd Annual Carolina Poultry Nutrition Conference, Research Triangle Park, North Carolina, pp. 22.

Florou-Paneri P, Giannenas I, Christaki E, Govaris A and Botsoglou N (2006). Performance of chickens and oxidative stability of the produced meat as affected by feed supplementation with oregano, vitamin C, vitamin E and their combinations. Archiv Fur Geflügelkunde 70: 232-240.

Fosgerau K and Hoffmann T (2015). Peptide therapeutics: current status and future directions. Drug Discovery Today 20: 122-128.

Fowler J, Li W and Bailey C (2015). Effects of a calcium bentonite clay in diets containing aflatoxin when measuring liver residues of aflatoxin B1 in starter broiler chicks. Toxins 7: 3455-3464.

Francois AC (1961). Mode of action of antibiotics on growth. World Review of Nutrition and Dietetics 3: 21-64.

Franz C, Baser KHC and Windisch W (2010). Essential oils and aromatic plants in animal feeding-a European perspective-A review. Flavour and Fragrance Journal 25: 327-340.

Fuller R (1989). Probiotics in man and animals. Journal of Applied Bacteriology 66: 365-378.

Gadde U, Rathinam T and Lillehoj HS (2015). Passive immunization with hyperimmune egg-yolk IgY as prophylaxis and therapy for poultry diseases - a review. Animal Health Research Reviews 16: 163-176.

Gaskins HR, Collier CT and Anderson DB (2002). Antibiotics as growth promotants: mode of action. Animal Biotechnology 13: 2942.

Geier MS, Torok VA, Allison GE, Ophel-Keller K and Hughes RJ (2009). Indigestible carbohydrates alter the intestinal microbiota but do not influence the performance of broiler chickens. Journal of Applied Microbiology 106: 1540-1548.

Ghazanfari S, Mohammadi Z and Moradi AM (2015). Effects of coriander essential oil on the performance, blood characteristics, intestinal microbiota and histology of broilers. Brazilian Journal of Poultry Science 17: 419-426.
Gibson GR and Roberfroid MB (1995). Dietary modulation of the human colonic microbiota: introducing the concept of prebiotics. Journal of Nutrition 125: 1401-1412.

Goldberg AL, Baracos V, Rodemann P, Waxman L and Dinarello C (1984). Control of protein degradation in muscles by prostaglandins, $\mathrm{Ca}^{2+}$ and leukocyte pyrogen (interleukin-1). Federation Proceedings 43: 1301-1306.

Goode DH, Allen VM and Barrow PA (2003). Reduction of experimental Salmonella and Campylobacter contamination of chicken skin by application of lytic bacteriophage. Applied Environmental Microbiology 69: 5032-5036.

Goñi I, Brenes A, Centeno C, Viveros A, Saura-Calixto F, Rebolé A, Arija I and Estevez R (2007). Effect of dietary grape pomace and vitamin $\mathrm{E}$ on growth performance, nutrient digestibility, and susceptibility to meat lipid oxidation in chickens. Poultry Science 86: $508-516$.

Greko C (2001). Safety aspects on non-use of antimicrobials as growth promoters. In: Piva A, Bach Knudsen KE and Lindberg KE (eds) Gut Environment of Pigs. Nottingham: Nottingham University Press, pp. 219-230.

Griggs JP and Jacob JP (2005). Alternatives to antibiotics for organic poultry production. Journal of Applied Poultry Research 14: 750-756.

Groschke AC and Evans RJ (1950). Effects of antibiotics, synthetic vitamins, vitamin $B_{12}$ and an APF supplement on chick growth. Poultry Science 29: 616-618.

Guban J, Korver DR, Allison GE and Tannock GW (2006). Relationship of dietary antimicrobial drug administration with broiler performance, decreased population levels of Lactobacillus Salivarius, and reduced bile salt deconjugation in the ileum of broiler chickens. Poultry Science 85: 2186-2194.

Guo FC, Kwakkel RP, Soede J, Williams BA and Verstegen MWA (2004). Effect of a Chinese herb medicine formulation, as an alternative for antibiotics, on performance of broilers. British Poultry Science 45: 793-797.

Han W, Zhang XL, Wang DW, Li LY, Liu GL and Zhao YX (2013). Effects of microencapsulated Enterococcus faecalis CG1.0007 on growth performance, antioxidation activity, and intestinal microbiota in broiler chickens. Journal of Animal Science 91: 4374-4382.

Haque MN, Islam KM, Akbar MA, Chowdhury R, Khatun M, Karim MR and Kemppainen BW (2010). Effect of dietary citric acid, flavomycin and their combination on the performance, tibia ash and immune status of broiler. Canadian Journal of Animal Science 90: $57-63$

Hashemipour H, Kermanshahi H, Golian A and Veldkamp T (2013). Effect of thymol and carvacrol feed supplementation on performance, antioxidant enzyme activities, fatty acid composition, digestive enzyme activities, and immune response in broiler chickens. Poultry Science 92: 2059-2069.

Hashemipour H, Kermanshahi H, Golian A and Khaksar V (2014). Effects of carboxy methyl cellulose and thymol + carvacrol on performance, digesta viscosity and some blood metabolites of broilers. Journal of Animal Physiology and Animal Nutrition 98: 672-679.

Heo JM, Opapeju FO, Pluske JR, Kim JC, Hampson DJ and Nyachoti CM (2013). Gastrointestinal health and function in weaned pigs: a review of feeding strategies to control post-weaning diarrhea without using in-feed antimicrobial compounds. Journal of Animal Physiology and Animal Nutrition 97: 207-237.

Hernández F, Madrid J, García V, Orengo J and Megías MD (2004). Influence of two plant extracts on broiler performance, digestibility, and digestive organ size. Poultry Science 83: 169-174.

Hernández F, Garcia V, Madrid J, Orengo J, Catalá P and Megias MD (2006). Effect of formic acid on performance, digestibility, intestinal histomorphology and plasma metabolite levels of broiler chickens. British Poultry Science 47: 50-56.

Hoda AA and Maha MH (1995). Potency of copper as growth promoter in broiler chickens. Veterinary Medical Journal 43: 77-85.

Højberg O, Canibe N, Poulsen HD, Hedemann MS and Jensen BB (2005). Influence of dietary zinc oxide or copper sulfate on the 
gastrointestinal ecosystem in newly weaned piglets. Applied and Environmental Microbiology 71: 2267-2277.

Hooge DM (2004). Meta-analysis of broiler chicken pen trials evaluating dietary mannan oligosaccharide, 1993-2003. International Journal of Poultry Science 3: 163-174.

Hooge DM and Connolly A (2011). Meta-analysis summary of broiler chicken trials with dietary Actigen ${ }^{\circledR}(2009-2011)$. International Journal of Poultry Science 10: 819-824.

Hooge DM, Sims MD, Sefton AE, Connolly A and Spring P (2003). Effect of dietary mannan oligosaccharide, with or without Bacitracin or Virginiamycin, on live performance of broiler chickens at relatively high stocking density on new litter. Journal of Applied Poultry Research 12: 461-467.

Hooge DM, Pierce JL, McBride KW and Rigolin PJ (2010). Meta-analysis of broiler chicken trials using diets with or without Allzyme $^{(\mathbb{S}}$ SSF enzyme complex. International Journal of Poultry Science 9: 819-823.

Houshmand M, Azhar K, Zulkifli I, Bejo MH and Kamyab A (2012). Effects of prebiotic, protein level, and stocking density on performance, immunity, and stress indicators of broilers. Poultry Science 91: 393-401.

Huang MK, Choi YJ, Houde R, Lee JW, Lee B and Zhao X (2004). Effects of Lactobacilli and an acidophilic Fungus on the production performance and immune responses in broiler chickens. Poultry Science 83: 788-795.

Huff WE, Huff GR, Rath NC, Balog JM and Donoghue AM (2003). Bacteriophage treatment of a severe Escherichia coli respiratory infection in broiler chickens. Avian Diseases 47: 1399-1405.

Huff WE, Huff GR, Rath NC, Balog JM and Donoghue AM (2004). Bacteriophage: potential role in food safety. In: Beier RC, Pillai SD, Phillips TD and Ziprin RL (eds) Preharvest and Postharvest Food Safety Contemporary Issues and Future Directions. Ames, Iowa: Blackwell Publishing, pp. 365-374.

Huff WE, Huff GR, Rath NC, Balog JM and Donoghue AM (2005). Alternative to antibiotics: utilization of bacteriophage to treat Colibacillosis and prevent foodborne pathogens. Poultry Science 84: 655-659.

Hume ME (2011). Historic perspective: prebiotics, probiotics, and other alternatives to antibiotics. Poultry Science 90: 2663-2669.

Huyghebaert G, Ducatelle R, and Van Immerseel F (2011). An update on alternatives to antimicrobial growth promoters for broilers. The Veterinary Journal 187: 182-188.

Isabel B and Santos Y (2009). Effects of dietary organic acids and essential oils on growth performance and carcass characteristics of broiler chickens. Journal of Applied Poultry Research 18: 472-476.

Islam RM, Oomah DB and Diarra MS (2016). Potential immunomodulatory effects of non-dialyzable materials of cranberry extract in poultry production. Poultry Science 1-10. [Available online at http://dx.doi.org/10.3382/ps/pew302.]

Issa KJ and Omar JMA (2012). Effect of garlic powder on performance and lipid profile of broilers. Open Journal of Animal Sciences 2: 62-68.

Jackson ME and Hanford K (2014). Statistical meta-analysis of pen trials conducted testing heat-sensitive $\beta$-mannanase (Hemicell) feed enzyme in male broilers grown to market age. Poultry Science 93 (E-suppl. 1): 66.

Jamroz D, Orda J, Kamel C, Wiliczkiewicz A, Wertelecki T and Skorupinska J (2003). The influence of phytogenic extracts on performance, nutrient digestibility, carcass characteristics, and gut microbial status in broiler chickens. Journal of Animal and Feed Sciences 12: 583-596.

Janardhana V, Broadway MM, Bruce MP, Lowenthal JW, Geier MS, Hughes RJ and Bean AGD (2009). Prebiotics modulate immune responses in the gut-associated lymphoid tissue of chickens. Journal of Nutrition 139: 1404-1409.

Jang IS, Ko YH, Kang SY and Lee CY (2007). Effect of a commercial essential oil on growth performance, digestive enzyme activity and intestinal microflora population in broiler chickens. Animal Feed Science and Technology 134: 304-315.
Jeong JS and Kim IH (2014). Effect of Bacillus subtilis C-3102 spores as a probiotic feed supplement on growth performance, noxious gas emission, and intestinal microflora in broilers. Poultry Science 93: 3097-3103.

Jin LZ, Ho YW, Abdullah N and Jalaludiin S (1998). Growth performance, intestinal microbial populations, and serum cholesterol of broilers fed diets containing Lactobacillus cultures. Poultry Science 77: 1259-1265.

Jin LZ, Ho YW, Abdullah N and Jalaludin S (2000). Digestive and bacterial enzyme activities in broilers fed diets supplemented with Lactobacillus cultures. Poultry Science 79: 886-891.

Joerger RD (2003). Alternatives to antibiotics: bacteriocins, antimicrobial peptides and bacteriophages. Poultry Science 82: 640-647.

Jørgensen H, Zhao XQ, Theil PK and Jakobsen K (2008). Effect of graded levels of rapeseed oil in isonitrogenous diets on the development of the gastrointestinal tract, and utilisation of protein, fat and energy in broiler chickens. Arcbives of Animal Nutrition 62: 331342.

Jorge de Lemos M, Calixto LFL, Alves ODS, Santos de Souza D, Moura BB and Reis TL (2015). Kaolin in the diet and its effects of performance, litter moisture and intestinal morphology of broiler chickens. Ciência Rural 45: 1835-1840.

Józefiak D, Kaczmarek S and Rutkowski A (2008). A note on the effects of selected prebiotics on the performance and ileal microbiota of broiler chickens. Journal of Animal and Feed Sciences 17: 392 397.

Józefiak D, Sip A, Kaczmarek S and Rutkowski A (2010). Effects of Carnobacterium divergens AS7 bacteriocin on gastrointestinal microflora in vitro and on nutrient retention in broiler chickens. Journal of Animal and Feed Sciences 19: 460-467.

Józefiak D, Sip A, Rawski M, Steiner T and Rutkowski A (2011a). The dose response effects of liquid and lyophilized Carnobacterium divergens AS7 bacteriocin on the nutrient retention and performance of broiler chickens. Journal of Animal and Feed Sciences 20: 401-411.

Jozefiak D, Sip A, Rawski M, Rutkowski A, Kaczmarek S, Hojberg O, Jensen BB and Engberg RM (2011b). Dietary divercin modifies gastrointestinal microbiota and improves growth performance in broiler chickens. British Poultry Science 52: 492-499.

Józefiak D, Sip A, Rutkowski A, Rawski M, Kaczmarek S, Wołun-Cholewa M, Engberg RM and Højberg O (2012). Lyophilized Carnobacterium divergens AS7 bacteriocin preparation improves performance of broiler chickens challenged with Clostridium perfringens. Poultry Science 91: 1899-1907.

Józefiak D, Kierończyk B, Juśkiewicz J, Zduńczyk Z, Rawski M, Dlugosz J, Sip A and Højberg O (2013). Dietary nisin modulates the gastrointestinal microbial ecology and enhances growth performance of the broiler chickens. PLoS ONE 8: e85347.

Jukes TH, Stokstad ELR, Taylor RR, Cunha TJ, Edwards HM and Meadows GB (1950). Growth-promoting effects of aureomycin on pigs. Archives of Biochemistry and Biophysics 26: 324-325.

Juskiewicz J, Gruzauskas R, Zdunczyk Z, Semaskaite A, Jankowski J, Totilas Z, Jarule V, Sasyte V, Zdunczyk P, RaceviciuteStupeliene A and Svirmickas G (2011). Effects of dietary addition of Macleaya cordata alkaloid extract on growth performance, caecal indices and breast meat fatty acids profile in male broilers. Journal of Animal Physiology and Animal Nutrition 95: 171-178.

Jung SJ, Houde R, Baurhoo B, Zhao X and Lee BH (2008). Effects of galacto-oligosaccharides and a Bifidobacteria lactis-based probiotic strain on the growth performance and fecal microflora of broiler chickens. Poultry Science 87: 1694-1699.

Kabir SML (2009). The role of probiotics in the poultry industry. International Journal of Molecular Sciences 10: 3531-3546.

Kabir SML, Rahman MM, Rahman MB, Rahman MM and Ahmed SU (2004). The dynamics of probiotics on growth performance and immune response in broilers. International Journal of Poultry Science 3: $361-364$.

Kalavathy R, Abdullah N, Jalaludin S and Ho YW (2003). Effects of Lactobacillus cultures on growth performance, abdominal fat 
deposition, serum lipids and weight of organs of broiler chickens. British Poultry Science 44: 139-144.

Karadas F, Pirgozliev V, Rose SP, Dimitrov D, Oduguwa O and Bravo D (2014). Dietary essential oils improve the hepatic antioxidative status of broiler chickens. British Poultry Science 55: 329-334.

Karaoglu M and Durdag H (2005). The influence of dietary probiotic (Saccharomyces cerevisiae) supplementation and different slaughter age on the performance, slaughter and carcass properties of broilers. International Journal of Poultry Science 4: 309-316.

Katouli MS, Boldaji F, Dastar B and Hassani S (2010). Effect of different levels of kaolin, bentonite and zeolite on broilers performance. Journal of Biological Sciences 10: 58-62.

Khalaji S, Zaghari M, Hatami KH, Hedari-Dastjerdi S, Lotfi L and Nazarian H (2011). Black cumin seeds, Artemisia leaves (Artemisia sieber), and Camellia L. plant extract as phytogenic products in broiler diets and their effects on performance, blood constituents, immunity, and cecal microbial population. Poultry Science 90: $2500-2510$.

Khan M, Raoult D, Richet H, Lepidi H and La Scola B (2007). Growth-promoting effects of single-dose intragastrically administered probiotics in chickens. British Poultry Science 48: 732-735.

Khattak F, Ronchi A, Castelli P and Sparks N (2014). Effects of natural blend of essential oil on growth performance, blood biochemistry, cecal morphology, and carcass quality of broiler chickens. Poultry Science 93: 132-137.

Kiarie E, Romero LF and Nyachoti CM (2013). The role of added feed enzymes in promoting gut health in swine and poultry. Nutrition Research Reviews 26: 71-88.

Kim DK, Lillehoj HS, Lee SH, Jang SI and Bravo D (2010). High-throughput gene expression analysis of intestinal intraepithelial lymphocytes after oral feeding of carvacrol, cinnamaldehyde, or Capsicum oleoresin. Poultry Science 89: 68-81.

Kim GB, Seo YM, Kim CH and Paik IK (2011). Effect of dietary prebiotic supplementation on the performance, intestinal microflora, and immune response of broilers. Poultry Science 90: 75-82.

Kim JS, Ingale SL, Kim YW, Kim KH, Sen S, Ryu MH, Lohakare JD, Kwon IK and Chae BJ (2012). Effect of supplementation of multi-microbe probiotic product on growth performance, apparent digestibility, cecal microbiota and small intestinal morphology of broilers. Journal of Animal Physiology and Animal Nutrition 96: 618-626.

Kim DK, Lillehoj HS, Lee SH, Jang SI, Park MS, Min W, Lillehoj EP and Bravo D (2013a). Immune effects of dietary anethole on Eimeria acervulina infection. Poultry Science 92: 2625-2634.

Kim DK, Lillehoj HS, Lee SH, Lillehoj EP and Bravo D (2013b). Improved resistance to Eimeria acervulina infection in chickens due to dietary supplementation with garlic metabolites. British Journal of Nutrition 109: 76-88.

Kim SC, Kim JW, Kim JU and Kim IH (2013c). Effects of dietary supplementation of bacteriophage on growth performance, nutrient digestibility, carcass characteristics and fecal microflora in broilers. Korean Journal of Poultry Science 40: 75-81.

Kim JW, Kim JH and Kil DY (2015). Dietary organic acids for broiler chickens: a review. Colombian Journal of Animal Science and Veterinary Medicine 28: 109-123.

Kim SJ, Lee KW, Kang CW and An BK (2016a). Growth performance, relative meat and organ weights, cecal microflora, and blood characteristics in broiler chickens fed diets containing different nutrient density with or without essential oils. Asian Australasian Journal of Animal Science 29: 549-554.

Kim WH, Lillehoh HS and Gay CG (2016b). Using genomics to identify novel antimicrobials. Revue scientifique et technique 35: 95-103.

Klasing KC, Laurin DE, Peng PK and Fry DM (1987). Immunologically mediated growth depression in chicks: influence of feed intake, corticosterone and interleukin-1. The Journal of Nutrition 117: 1629-1637.

Knarreborg A, Lauridsen C, Engberg RM and Jensen SK (2004). Dietary antibiotic growth promoters enhance the bioavailability of alpha-tocopheryl acetate in broilers by altering lipid absorption. Journal of Nutrition 134: 1487-1492.

Koczulla AR and Bals R (2003). Antimicrobial peptides: current status and therapeutic potential. Drugs 63: 389-406.

Kubena LF, Harvey RB, Bailey RH, Buckley SA and Rottinghaus GE (1998). Effects of a hydrated sodium calcium aluminosilicate (T-Bind ${ }^{\mathrm{TM}}$ ) on mycotoxicosis in young broiler chickens. Poultry Science 77: 1502-1509.

Kurtoglu V, Kurtoglu F, Seker E, Coskun B, Balevi T and Polat ES (2004). Effect of probiotic supplementation on laying hen diets on yield performance and serum and egg yolk cholesterol. Food Additives and Contaminants 21: 817-823.

Lee KW, Everts H, Kappert HJ, Frehner M, Losa R and Beynen AC (2003). Effects of dietary essential oil components on growth performance, digestive enzymes and lipid metabolism in female broiler chickens. British Poultry Science 44: 450-457.

Lee SH, Lillehoj HS, Chun HK, Tuo W, Park HJ, Cho SM, Lee YM and Lillehoj EP (2007). In vitro treatment of chicken peripheral blood lymphocytes, macrophages and tumor cells with extracts of Korean medicinal plants. Nutrition Research 27: 362-366.

Lee SH, Lillehoj HS, Park DW, Jang SI, Morales A, Garcia D, Lucio E, Larios R, Victoria G, Marrufo D, and Lillehoj EP (2009a). Induction of passive immunity in broiler chickens against Eimeria acervulina by hyperimmune egg yolk immunoglobulin Y. Poultry Science 88: 562-566.

Lee SH, Lillehoj HS, Park DW, Jang SI, Morales A, Garcia D, Lucio E, Larios R, Victoria G, Marrufo D, and Lillehoj EP (2009b). Protective effect of hyperimmune egg yolk $\operatorname{IgY}$ antibodies against Eimeria tenella and Eimeria maxima infections. Veterinary Parasitology 163: 123-126.

Lee KW, Lee SH, Lillehoj HS, Li GX, Jang SI, Babu US, Park MS, Kim DK, Lillehoj EP, Neumann AP, Rehberger TG and Siragusa GR (2010a). Effects of direct-fed microbials on growth performance, gut morphometry, and immune characteristics in broiler chickens. Poultry Science 89: 203-216.

Lee SH, Lillehoj HS, Hong YH, Jang SI, Lillehoj EP, Ionescu C, Mazuranok L and Bravo D (2010b). In vitro effects of plant and mushroom extracts on immunological function of chicken lymphocytes and macrophages. British Poultry Science 51: 213-221.

Lee KW, Lillehoj HS and Siragusa GR (2010c). Direct-fed microbials and their impact on the intestinal microflora and immune system of chickens. Journal Poultry Science 47: 106-114.

Lee KW, Li G, Lillehoj HS, Lee SH, Jang SI, Babu US, Lillehoj EP, Neumann AP and Siragusa GR (2011a). Bacillus subtilis-based direct-fed microbials augment macrophage function in broiler chickens. Research in Veterinary Science 91: e87-e91.

Lee SH, Lillehoj HS, Jang SI, Lee KW, Park MS, Bravo D and Lillehoj EP (2011b). Cinnamaldehyde enhances in vitro parameters of immunity and reduces in vivo infection against avian coccidiosis. British Journal of Nutrition 106: 862-869.

Lei K, Li YL, Yu DY, Rajput IR and Li WF (2013). Influence of dietary inclusion of Bacillus licheniformis on laying performance, egg quality, antioxidant enzyme activities, and intestinal barrier function of laying hens. Poultry Science 92: 2389-2395.

Leusink G, Rempel H, Skura B, Berkyto M, White W, Yang Y, Rhee JY, Xuan SY, Chiu S, Silversides F, Fitzpatrick S and Diarra MS (2010). Growth performance, meat quality, and gut microflora of broiler chickens fed with cranberry extract. Poultry Science 89: 1514-1523.

Li Y, Xiang Q, Zhang Q, Huang Y and Su Z (2012). Overview on the recent study of antimicrobial peptides: origins, functions, relative mechanisms and application. Peptides 37: 207-215.

Liao XD, Ma G, Cai J, Fu Y, Yan XY, Wei XB and Zhang RJ (2015). Effects of Clostridium butyricum on growth performance, antioxidation, and immune function of broilers. Poultry Science 94: 662-667.

Lillehoj HS, Kim DK, Bravo DM and Lee SH (2011). Effects of dietary plant-derived phytonutrients on the genome-wide profiles and coccidiosis resistance in the broiler chickens. BioMed Central Proceedings 5: S34. 
Lin J (2011). Effect of antibiotic growth promoters on intestinal microbiota in food animals: a novel model for studying the relationship between gut microbiota and human obesity? Frontiers in Microbiology 2: 53.

Lin J (2014). Antibiotic growth promoters enhance animal production by targeting intestinal bile salt hydrolase and its producers. Frontiers in Microbiology 5: 33.

Lin J, Hunkapiller AA, Layton AC, Chang YJ and Robbins KR (2013). Response of intestinal microbiota to antibiotic growth promoters in chickens. Foodborne Pathogens and Disease 10: 331-337.

Linde A, Ross CR, Davis EG, Dib L, Blecha F and Melgarejo T (2008). Innate immunity and host defense peptides in veterinary medicine. Journal of Veterinary Internal Medicine 22: 247-265.

Liu T, She R, Wang K, Bao H, Zhang Y, Luo D, Hu Y, Ding Y, Wang D and Peng K (2008). Effects of rabbit sacculus rotundus antimicrobial peptides on the intestinal mucosal immunity in chickens. Poultry Science 87: 250-254.

Liu X, Yan H, Lv L, Xu Q, Yin C, Zhang K, Wang P and Hu J (2012). Growth performance and meat quality of broiler chickens supplemented with Bacillus licheniformis in drinking water. Asian-Australasian Journal of Animal Sciences 25: 682-689.

Liu HN, Liu Y, Hu LL, Suo YL, Zhang L, Jin F, Feng XA, Teng N and Li Y (2014). Effects of dietary supplementation of quercetin on performance, egg quality, cecal microflora populations, and antioxidant status in laying hens. Poultry Science 93: 347-353.

Lu L, Wang RL, Zhang ZJ, Steward FA, Luo X and Liu B (2010). Effect of dietary supplementation with copper sulfate or tribasic copper chloride on the growth performance, liver copper concentrations of broilers fed in floor pens, and stabilities of vitamin $\mathrm{E}$ and phytase in feeds. Biological Trace Element Research 138: 181-189.

Luecke RW, McMillen WN and Thorp F Jr (1950a). The effects of vitamin $\mathrm{B}_{12}$, animal protein factor and streptomycin on the growth of young pigs. Archives of Biochemistry and Biophysics 26: 326-327.

Luecke RW, Newland HW, McMillen WN and Thorp F Jr (1950b). The effects of antibiotics fed at low levels on the growth of weaning pigs. Journal of Animal Science 9: 662.

Malayoğlu HB, Baysal Ş, Misirlioğlu Z, Polat M, Yilmaz H and Turan N (2010). Effects of oregano essential oil with or without feed enzymes on growth performance, digestive enzyme, nutrient digestibility, lipid metabolism and immune response of broilers fed on wheat-soybean meal diets. British Poultry Science 51: 67-80.

McGinnis J (1950). The antibiotics make good feeds better. Turkey World July, pp. 11.

Medeiros MA, Oliveira DC, Rodrigues Ddos P and Freitas DR (2011). Prevalence and antimicrobial resistance of Salmonella in chicken carcasses at retail in 15 Brazilian cities. Pan American Journal of Public Health 30: 555-560.

M'ikanatha NM, Sandt CH, Localio AR, Tewari D, Rankin SC, Whichard JM, Altekruse SF, Lautenbach E, Folster JP, Russo A, Chiller TM, Reynolds SM and McDermott PF (2010). Multidrug-resistant Salmonella isolates from retail chicken meat compared with human clinical isolates. Foodborne Pathogens and Diseases 7: 929-934.

Miller RW, Skinner EJ, Sulakvelidze A, Mathis GF and Hofacre CL (2010). Bacteriophage therapy for control of necrotic enteritis of broiler chickens experimentally infected with Clostridium perfringens. Avian Diseases 54: 33-40.

Mohamed MA, Hassan HMA and El-Barkouky EMA (2008). Effect of mannan oligosaccharide on performance and carcass characteristics of broiler chicks. Journal of Agriculture and Social Sciences 4: 13-17.

Mohnl M, Acosta Aragón Y, Acosta Ojeda A, Rodríguez Sánchez B and Pasteiner S (2007). Effect of synbiotic feed additive in comparison to antibiotic growth promoter on performance and health status of broilers. Poultry Science 86 (suppl. 1): 217.

Mookiah S, Sieo CC, Ramasamy K, Abdullah N and Ho YW (2014). Effects of dietary prebiotics, probiotic and synbiotics on performance, caecal bacterial populations and caecal fermentation concentrations of broiler chickens. Journal of the Science of Food and Agriculture 94: 341-348.

Moore PR, Evenson A, Luckey TD, McCoy E, Elvehjem CA and Hart EB (1946). Use of sulfasuxidine, streptothricin and streptomycin in nutritional studies with the chick. Journal of Biological Chemistry 165: 437-441.

Mountzouris KC, Tsirtsikos P, Kalamara E, Nitsch E, Schatzmayr G and Fegeros K (2007). Evaluation of the efficacy of a probiotic containing Lactobacillus, Bifidobacterium, Enterococcus, and Pediococcus strains in promoting broiler performance and modulating cecal microflora composition and metabolic activities. Poultry Science 86: 309-317.

Mountzouris KC, Tsirtsikos P, Palamidi I, Arvaniti A, Mohnl M, Schatzmayr G and Fegeros K (2010). Effects of probiotic inclusion levels in broiler nutrition on growth performance, nutrient digestibility, plasma immunoglobulins, and cecal microflora composition. Poultry Science 89: 58-67.

Mueller K, Blum NM, Kluge H and Mueller AS (2012). Influence of broccoli extract and various essential oils on performance and expression of xenobiotic- and antioxidant enzymes in broiler chickens. British Journal of Nutrition 108: 588-602.

Murugesan GR, Syed B, Haldar S and Pender C (2015). Phytogenic feed additives as an alternative to antibiotic growth promoters in broiler chickens. Frontiers in Veterinary Science 2: 21.

Nakphaichit M, Thanomwongwattana S, Phraephaisarn C, Sakamoto N, Keawsompong S, Nakayama J and Nitisinprasert S (2011). The effect of including Lactobacillus reuteri KUB-AC5 during post-hatch feeding on the growth and ileum microbiota of broiler chickens. Poultry Science 90: 2753-2765.

Nava GM, Attene-Ramos MS, Gaskins HR and Richards JD (2009). Molecular analysis of microbial community structure in the chicken ileum following organic acid supplementation. Veterinary Microbiology 137: 345-353.

Nayebpor M, Farhomand P and Hashemi A (2007). Effects of different levels of direct fed microbial (Primalac) on growth performance and humoral immune response in broiler chickens. Journal of Animal and Veterinary Advances 6: 1308-1313.

Niewold TA (2007). The nonantibiotic anti-inflammatory effect of antimicrobial growth promoters, the real mode of action? A hypothesis. Poultry Science 86: 605-609.

Netherwood T, Gilbert HJ, Parker DS, and O’Donnell AG (1999). Probiotics shown to change bacterial community structure in the avian gastrointestinal tract. Applied and Environmental Microbiology 65: 5134-5138.

Nezhad YE, Gale-Kandi JG, Farahvash T and Yeganeh AR (2011). Effect of combination of citric acid and microbial phytase on digestibility of calcium, phosphorous and mineralization parameters of tibia bone in broilers. African Journal of Biotechnology 10: 15089-15093.

Ng SC, Hart AL, Kamm MA, Stagg AJ and Knight SC (2009). Mechanisms of action of probiotics: recent advances. Inflammatory Bowel Diseases 15: 300-310.

Nurmi E and Rantala M (1973). New aspects of Salmonella infection in broiler production. Nature 241: 210-211.

O'Dea EE, Fasenko GM, Allison GE, Korver DR, Tannock GW and Guan LL (2006). Investigating the effects of commercial probiotics on broiler chick quality and production efficiency. Poultry Science 85: 1855-1863.

Ohh SH, Shinde PL, Jin Z, Choi JY, Hahn TW, Lim HT, Kim GY, Park Y, Hahm KS and Chae BJ (2009). Potato (Solanum tuberosum L. cv. Gogu valley) protein as an antimicrobial agent in the diets of broilers. Poultry Science 88: 1227-1234.

Olver MD (1997). Effect of feeding clinoptilolite (zeolite) on the performance of three strains of laying hens. British Poultry Science 38: 220-222.

Panda AK, Rama Rao SV, Raju MVLN and Shyam Sunder G (2009). Effect of butyric acid on performance, gastrointestinal tract health and carcass characteristics in broiler chickens. Asian-Australasian Journal of Animal Science 22: 1026-1031. 
Park JH and Kim IH (2014). Supplemental effect of probiotic Bacillus subtilis B2A on productivity, organ weight, intestinal Salmonella microflora, and breast meat quality of growing broiler chicks. Poultry Science 93: 2054-2059.

Park IJ, Cha SY, Kang M, So YS, Go HG, Mun SP, Ryu KS and Jang HK (2011). Effect of proanthocyanidin-rich extract from Pinus radiata bark on immune response of specific-pathogen-free White Leghorn chickens. Poultry Science 90: 977-982.

Parvez S, Malik KA, Ah Kang S and Kim HY (2006). Probiotics and their fermented food products are beneficial for health. Journal of Applied Microbiology 100: 1171-1185.

Patterson JA and Burkholder KM (2003). Application of prebiotics and probiotics in poultry production. Poultry Science 82: 627-631.

Patten JD and Waldroup PW (1988). Use of organic acids in broiler diets. Poultry Science 67: 1178-1182.

Pedroso AA, Menten JFM, Lambais MR, Racanicci AMC, Longo FA and Sorbara JOB (2006). Intestinal bacterial community and growth performance of chickens fed diets containing antibiotics. Poultry Science 85: 747-752.

Pesti GM and Bakalli RI (1996). Studies on the feeding of cupric sulfate pentahydrate and cupric citrate to broiler chickens. Poultry Science 75: 1086-1091.

Pierce J, Ao T, Charlton P and Tucker LA (2009). Organic minerals for broilers and laying hens: reviewing the status of research so far. World's Poultry Science Journal 65: 493-498.

Pimentel JL and Cook ME (1988). Improved growth in the progeny of hens immunized with jackbean urease. Poultry Science 67: 434-439.

Pimentel JL, Cook ME and Jonsson JM (1991). Increased growth of chicks and poults obtained from hens injected with jackbean urease. Poultry Science 70: 1842-1844.

Pirgozliev V, Bravo D, Mirza MW and Rose SP (2015). Growth performance and endogenous losses of broilers fed wheat-based diets with and without essential oils and xylanase supplementation. Poultry Science 94: 1227-1232.

Pourabedin M and Zhao X (2015). Prebiotics and gut microbiota in chickens. FEMS Microbiology Letters 362: fnv122.

Pourabedin M, Xu Z, Baurhoo B, Chevaux E and Zhao X (2014). Effects of mannan oligosaccharide and virginiamycin on the cecal microbial community and intestinal morphology of chickens raised under suboptimal conditions. Canadian Journal of Microbiology 60: 255-266.

Pourhossein Z, Qotbi AAA, Seidavi A, Laudadio V, Centoducati G and Tufarelli V (2015). Effect of different levels of dietary sweet orange (Citrus sinensis) peel extract on humoral immune system responses in broiler chickens. Animal Science Journal 86: $105-110$.

Phillips TD (1999). Dietary clay in the chemoprevention of aflatoxininduced disease. Toxicological Sciences 52: 118-126.

Placha I, Takacova J, Ryzner M, Cobanova K, Laukova A, Strompfova V, Venglovska K and Faix S (2014). Effect of thyme essential oil and selenium on intestine integrity and antioxidant status of broilers. British Poultry Science 55: 105-114.

Prvulović D, Kojić D, Grubor-Lajsić G and Kosarcić S (2008). The effects of dietary inclusion of hydrated aluminosilicate on performance and biochemical parameters of broiler chickens. Turkish Journal of Veterinary and Animal Sciences 32: 183-189.

Rafacz-Livingston KA, Parsons CM and Jungk RA (2005). The effects of various organic acids on phytate phosphorous utilization in chicks. Poultry Science 84: 1356-1362.

Ravindran V and Son JH (2011). Feed enzyme technology: present status and future developments. Recent Patents on Food Nutrition and Agriculture 3: 102-109.

Rebolé A, Ortiz LT, Rodríguez ML, Alzeuta C, Treviño J and Velasco S (2010). Effects of inulin and enzyme complex, individually or in combination, on growth performance, intestinal microflora, cecal fermentation characteristics, and jejunal histomorphology in broiler chickens fed a wheat- and barley-based diet. Poultry Science 89: 276-286.
Rezaei S, Jahromi MF, Liang JB, Zulkifli I, Farjam AS, Laudadio V and Tufarelli V (2015). Effect of oligosaccharides extract from palm kernel expeller on growth performance, gut microbiota and immune response in broiler chickens. Poultry Science 94: 24142420.

Richards JD, Zhao J, Harrell RJ, Atwell CA and Dibner JJ (2010). Trace mineral nutrition in poultry and swine. Asian-Australasian Journal of Animal Science 23: 1527-1534.

Ricke SC (2003). Perspectives on the use of organic acids and short chain fatty acids as antimicrobials. Poultry Science 82: 632639.

Ricke SC (2015). Potential of fructooligosaccharide prebiotics in alternative and nonconventional poultry production systems. Poultry Science 94: 1411-1418.

Riley MA and Wertz JE (2002). Bacteriocins: evolution, ecology, and application. Annual Review of Microbiology 56: 117-137.

Rosen GD (1995). Antibacterials in poultry and pig nutrition. In: Wallace $\mathrm{RJ}$ and Chesson A (eds) Biotecbnology in Animal Feeds and Animal Feeding. Weinheim, Germany, pp. 143-172.

Rosen GD (2007). Holo-analysis of the efficacy of Bio-Mos ${ }^{\circledR}$ in broiler nutrition. British Poultry Science 48: 21-26.

Rostami F, Ghasemi HA and Taherpour K (2015). Effect of Scrophularia striata and Ferulago angulata, as alternatives to virginiamycin, on growth performance, intestinal microbial population, immune response, and blood constituents of broiler chickens. Poultry Science 94: 2202-2209.

Rusoff LL, Davis AV and Alford JA (1951). Growth-promoting effect of aureomycin on young calves weaned from milk at an early age. Journal of Nutrition 45: 289-300.

Russell SM and Grimes JL (2009). The effect of a direct-fed microbial (Primalac) on turkey live performance. Journal of Applied Poultry Research 18: 185-192.

Salgado-Tránsito L, Del Río-García JC, Arjona-Román JL, Moreno-Martínez E and Méndez-Albores A (2011). Effect of citric acid supplemented diets on aflatoxin degradation, growth performance and serum parameters in broiler chickens. Arcbivos de Medicina Veterinaria 43: 215-222.

Salim HM, Kang HK, Akter N, Kim DW, Kim JH, Kim MJ, Na JC, Jong HB, Choi HC, Suh OS and Kim WK (2013). Supplementation of direct-fed microbials as an alternative to antibiotic on growth performance, immune response, cecal microbial population, and ileal morphology of broiler chickens. Poultry Science 92: 2084-2090.

Samanta S, Haldar S and Ghosh TK (2008). Production and carcass traits in broiler chickens given diets supplemented with inorganic trivalent chromium and an organic acid blend. British Poultry Science 49: 155-163.

Samanta S, Haldar S and Ghosh TK (2010). Comparative efficacy of an organic acid blend and bacitracin methylene disalicylate as growth promoters in broiler chickens: effects on performance, gut histology, and small intestinal milieu. Veterinary Medicine International 2010: 645150 .

Samantha AK, Jayapal N, Senani S, Kolte AP and Sridhar M (2013). Prebiotic inulin: useful dietary adjuncts to manipulate the livestock gut microflora. Brazilian Journal of Microbiology 44: 1-14.

Samli HE, Senkoylu N, Koc F, Kanter M and Agma A (2007). Effects of Enterococcus faecium and dried whey on broiler performance, gut histomorphology and intestinal microbiota. Archives of Animal Nutrition 61: 42-49.

Schiavone A, Guo K, Tassone S, Gasco L, Hernandez E, Denti R and Zoccarato I (2008). Effects of a natural extract of chestnut wood on digestibility, performance traits, and nitrogen balance of broiler chicks. Poultry Science 87: 521-527.

Schneitz C (2005). Competitive exclusion in poultry - 30 years of research. Food Control 16: 657-667.

Scott HM (2012). Heavy metals as alternatives to antibiotics: Panacea or Pandora's box? Paper presented at the International Symposium on Alternatives to Antibiotics, Paris, France, 25-28th September. 
Seal BS, Lillehoj HS, Donovan DM and Gay CG (2013). Alternatives to antibiotics: a symposium on the challenges and solutions for animal production. Animal Health Research Reviews 14: 78-87.

Selle PH and Ravindran V (2007). Microbial phytase in poultry nutrition. Animal Feed Science and Technology 135: 1-41.

Sen S, Ingale SL, Kim YW, Kim JS, Kim KH, Lohakare JD, Kim EK, Kim HS, Ryu MH, Kwon IK, Chae BJ (2012). Effect of supplementation of Bacillus Subtilis LS 1-2 to broiler diets on growth performance, nutrient retention, caecal microbiology and small intestinal morphology. Research in Veterinary Science 93: 264-268.

Settle T, Leonard SS, Falkenstein E, Fix N, Van Dyke K and Klandorf $H$ (2014). Effects of a phytogenic feed additive versus an antibiotic feed additive on oxidative stress in broiler chicks and a possible mechanism determined by Electron Spin Resonance. International Journal of Poultry Science 13: 62-69.

Shanmugasundaram R and Selvaraj RK (2012). Effect of killed whole yeast cell prebiotic supplementation on broiler performance and intestinal immune cell parameters. Poultry Science 91: 107-111.

Simon O, Jadamus A and Vahjen W (2001). Probiotic feed additives-effectiveness and expected modes of action. Journal of Animal and Feed Sciences 10: 51-67.

Simmering R and Blaut M (2001). Pro- and prebiotics-the tasty guardian angels? Applied Microbiology and Biotechnology 55: 19-28.

Skinner JT, Izat AL and Waldroup PW (1991). Research note: fumaric acid enhances performance of broiler chickens. Poultry Science 70: 1444-1447.

Slominski BA (2011). Recent advances in research on enzymes for poultry diets. Poultry Science 90: 2013-2023.

Sohail MU, Hume ME, Byrd JA, Nisbet DJ, Ijaz A, Sohail A, Shabbir MZ and Rehman H (2012). Effect of supplementation of prebiotic mannan-oligosaccharides and probiotic mixture on growth performance of broilers subjected to chronic heat stress. Poultry Science 91: 2235-2240.

Spring P, Wenk C, Dawson KA and Newman KE (2000). The effect of dietary mannonoligosaccharides on cecal parameters and the concentrations of enteric bacteria in the ceca of Salmonella-challenged broiler chicks. Poultry Science 79: 205-211.

Steiner T (2006). Managing Gut Health: Natural Growth Promoters as a Key to Animal Performance. Nottingham, UK: Nottingham University Press.

Sunder SG, Panda AK, Gopinath NCS, Rama Rao SV, Raju MVLN, Reddy MR and Vijay Kumar CH (2008). Effects of higher levels of zinc supplementation on performance, mineral availability, and immune competence in broiler chickens. Journal of Applied Poultry Research 17: 79-86.

Swann D and Romero L (2014). A meta-analysis on effect of a multienzyme solution on apparent ileal undigested starch, fat and crude protein in broilers. Poultry Science 93 (E-suppl. 1): 66-67.

Talebi A, Amirzadeh B, Mokhtari B and Gahri H (2008). Effects of a multi-strain probiotic (PrimaLac) on performance and antibody responses to Newcastle disease virus and infectious bursal disease virus vaccination in broiler chickens. Avian Pathology 37: 509-512.

Torres-Rodriguez A, Donoghue AM, Donoghue DJ, Barton JT, Tellez $G$ and Hargis BM (2007). Performance and condemnation rate analysis of commercial turkey flocks treated with a Lactobacillus spp.-based probiotic. Poultry Science 86: 444-446.

Torshizi MAK, Moghaddam AR, Rahimi S and Mojgani N (2010). Assessing the effect of administering probiotics in water or as a feed supplement on broiler performance and immune response. British Poultry Science 51: 178-184.

Thacker PA (2013). Alternatives to antibiotics as growth promoters for use in swine production: a review. Journal of Animal Science and Biotechnology 4: 35.

Thomke S and Elwinger K (1998). Growth promotants in feeding pigs and poultry. II. Mode of action of antibiotic growth promotants. Annales De Zootechnie 47: 153-167.

Tiihonen K, Kettunen H, Bento MHL, Saarinen M, Lahtinen S, Ouwehand AC, Schulze H and Rautonen N (2010). The effect of feeding essential oils on broiler performance and gut microbiota. British Poultry Science 51: 381-392.

Twort FW (1915). An investigation on the nature of ultramicroscopic viruses. Lancet 2: 1241-1243.

Van Der Klis JD and Vinyeta-Punti E (2014). The potential of phytogenic feed additives in pigs and poultry. In: Proceedings of 18th Congress of the European Society of Veterinary \& Comparative Nutrition, At Utrecht, Netherlands. Volume 18.

Van Der Wielen PW, Biesterveld S, Notermans S, Hofstra H, Urlings BA and Van Knapen F (2000). Role of volatile fatty acids in development of the cecal microflora in broiler chickens during growth. Applied and Environmental Microbiology 71: 2206-2207.

Vasanth S, Dipu MT, Mercy AD and Shyama K (2015). Efficiency of copper sulphate versus flavomycin as a growth promoter in broiler chickens. International Journal of Current Research 7: 16536-16539.

Verstegen MWA and Williams BA (2002). Alternatives to the use of antibiotics as growth promoters for monogastric animals. Animal Biotechnology 13: 113-127.

Vondruskova H, Slamova R, Trckova M, Zraly Z and Pavlik I (2010). Alternatives to antibiotic growth promoters in prevention of diarrhea in weaned piglets: a review. Veterinarni Medicina 55: 199-224.

Vilà B, Esteve-Garcia E and Brufau J (2010). Probiotic microorganisms: 100 years of innovation and efficacy; modes of action. World's Poultry Science Journal 65: 369-380.

Visek WJ (1978). The mode of growth promotion by antibiotics. Journal of Animal Science 46: 1447-1469.

Viveros A, Chamorro S, Pizarro M, Arija I, Centeno C and Brenes A (2011). Effects of dietary polyphenol-rich grape products on intestinal microflora and gut morphology in broiler chicks. Poultry Science 90: 566-578.

Waititu SM, Yitbarek A, Matini E, Echeverry H, Kiarie E, Rodriguez-Lecompte JC and Nyachoti CM (2014). Effect of supplementing direct-fed microbials on broiler performance, nutrient digestibilities, and immune responses. Poultry Science $\mathbf{9 3}$ : 625-635.

Wang Y and Gu Q (2010). Effect of probiotic on growth performance and digestive enzyme activity of Arbor Acres broilers. Research in Veterinary Science 89: 163-167.

Wang L, Piao XL, Kim SW, Piao XS, Shen YB and Lee HS (2008). Effects of Forsythia suspensa extract on growth performance, nutrient digestibility, and antioxidant activities in broiler chickens under high ambient temperature. Poultry Science 87: 1287-1294.

Wang D, Ma W, She R, Sun Q, Liu Y, Hu Y, Liu L, Yang Y and Peng K (2009). Effects of swine gut antimicrobial peptides on the intestinal mucosal immunity in specific-pathogen-free chickens. Poultry Science 88: 967-974.

Wang HT, Yu C, Hsieh YH, Chen SW, Chen BJ and Chen CY (2011). Effects of albusin B (a bacteriocin) of Ruminococcus albus 7 expressed by yeast on growth performance and intestinal absorption of broiler chickens - its potential role as an alternative to feed antibiotics. Journal of the Science of Food and Agriculture 91: 23382343.

Wang HT, Li YH, Chou IP, Hsieh YH, Chen BJ and Chen CY (2013a). Albusin B modulates lipid metabolism and increases antioxidant defense in broiler chickens by a proteomic approach. Journal of the Science of Food and Agriculture 93: 284-292.

Wang JP, Yan L, Lee JH and Kim IH (2013b). Evaluation of bacteriophage supplementation on growth performance, blood characteristics, relative organ weight, breast muscle characteristics and excreta microbial shedding in broilers. Asian-Australasian Journal of Animal Sciences 26: 573-578.

Wang K, Yan J, Dang W, Xie J, Yan B, Yan W, Sun M, Zhang B, Ma M, Zhao Y, Jia F, Zhu R, Chen W and Wang R (2014). Dual antifungal properties of cationic antimicrobial peptides polybia-MPI: membrane integrity disruption and inhibition of biofilm formation. Peptides 56: 22-29.

Wegener HC, Aarestrup FM, Jensen LB, Hammerum AM and Bager F (1999). Use of antimicrobial growth promoters in food animals 
and Enterococcus faecium resistance to therapeutic antimicrobial drugs in Europe. Emerging Infectious Diseases 5: 329-335.

Wen LF and He JG (2012). Dose-response effects of an antimicrobial peptide, a cecropin hybrid, on growth performance, nutrient utilization, bacterial counts in the digesta and intestinal morphology in broilers. The British Journal of Nutrition 108: 1756-1763.

Wierup M (2000). The control of microbial diseases in animals: alternatives to the use of antibiotics. International Journal of Antimicrobial Agents 14: 315-319.

Willey JM and van der Donk WA (2007). Lantibiotics: peptides of diverse structure and function. Annual Review of Microbiology 61: 477-501.

Willis WL, Isikhuemhen OS and Ibrahim SA (2007). Performance assessment of broiler chickens given mushroom extract alone or in combination with probiotics. Poultry Science 86: 1856-1860.

Windisch W, Schedle K, Plitzner C and Kroismayr A (2008). Use of phytogenic products as feed additives for swine and poultry. Journal of Animal Science 86: E140-E148.

Wise MG and Siragusa GR (2007). Quantitative analysis of the intestinal bacterial community in one-to three-week-old commercially reared broiler chickens fed conventional or antibiotic-free vegetablebased diets. Journal of Applied Microbiology 102: 1138-1149.

Witte W (1998). Medical consequences of antibiotic use in agriculture. Science 279: 996-997.

Whitehill AR, Oleson JJ and Hutchings BL (1950). Stimulatory effects of aureomycin in the growth of chicks. Ibid 74: 11-13.

Wolfenden AD, Pixley CM, Higgins JP, Higgins SE, Vicente JL, Torres-Rodriguez A, Hargis BM and Tellez G (2007). Evaluation of spray application of a Lactobacillus-based probiotic on Salmonella enteritidis colonization in broiler chickens. International Journal of Poultry Science 6: 493-496.

Wolfenden RE, Pumford NR, Morgan MJ, Shivaramaiah S, Wolfenden AD, Pixley CM, Green J, Tellez G and Hargis BM (2011). Evaluation of selected direct-fed microbial candidates on live performance and Salmonella reduction in commercial turkey brooding houses. Poultry Science 90: 2627-2631.

World Health Organization (2012). The evolving threat of antimicrobial resistance: options for action. [Available online at http://whqlibdoc. who.int/publications/2012/9789241503181_eng.pdf.] Accessed: 12 November 2015.

Woyengo TA and Nyachoti CM (2011). Review: supplementation of phytase and carbohydrases to diets for poultry. Canadian Journal of Animal Science 91: 177-192.

Wu Y, Wu Q, Zhou Y, Ahmad H and Wang T (2013). Effects of clinoptilolite on growth performance and antioxidant status in broilers. Biological Trace Element Research 155: 228-235.

Xia MS, Hu CH and Xu ZR (2004). Effects of copper-bearing montmorillonite on growth performance, digestive enzyme activities, and intestinal microflora and morphology of male broilers. Poultry Science 83: 1868-1875.

Xiao R, Power RF, Mallonee D, Routt K, Spangler L, Pescatore AJ, Cantor AH, Ao T, Pierce JL and Dawson KA (2012). Effects of yeast cell wall-derived mannan-oligosaccharides on jejunal gene expression in young broiler chickens. Poultry Science 91: 1660-1669.
Xu ZR, Hu CH, Xia MS, Zhan XA and Wang MQ (2003). Effects of dietary fructooligosaccharide on digestive enzyme activities, intestinal microflora and morphology of male broilers. Poultry Science 82: 1030-1036.

Xu QQ, Yan H, Liu XL, Lv L, Yin CH and Wang P (2014). Growth performance and meat quality of broiler chickens supplemented with Rhodopsedomonas palustris in drinking water. British Poultry Science 55: 360-366.

Yang Y, Iji PA and Choct M (2007). Effects of different dietary levels of mannanoligosaccharide on growth performance and gut development of broiler chickens. Asian-Australasian Journal of Animal Science 20: 1084-1091.

Yang CM, Cao GT, Ferket PR, Liu TT, Zhou L, Zhang L, Xiao YP and Chen AG (2012). Effects of probiotic, Clostridium butyricum, on growth performance, immune function, and cecal microflora in broiler chickens. Poultry Science 91: 2121-2131.

Yazdankhah S, Rudi K and Bernhoft A (2014). Zinc and copper in animal feed-development of resistance and co-resistance to antimicrobial agents in bacteria of animal origin. Microbial Ecology in Health and Disease 25: 25862.

Yeaman MR and Yount NY (2007). Unifying themes in host defence effector polypeptides. Nature Reviews Microbiology 5: 727-740.

Yeo J and Kim KI (1997). Effect of feeding diets containing an antibiotic, a probiotic, or yucca extract on growth and intestinal urease activity in broiler chicks. Poultry Science 76: 381-385.

Yitbarek A, Echeverry H, Munyaka P and Rodriguez-Lecompte JC (2015). Innate immune response of pullets fed diets supplemented with prebiotics and synbiotics. Poultry Science 94: 1802-1811.

Yogesh K, Deo C, Shrivastava HP, Mandal AB, Wadhwa A and Singh I (2013). Growth performance, carcass yield, and immune competence of broiler chickens as influenced by dietary supplemental zinc sources and levels. Agricultural Research 2: 270-274.

Zhao PY, Baek HY and Kim IH (2012). Effects of bacteriophage supplementation on egg performance, egg quality, excreta microflora, and moisture content in laying hens. Asian-Australasian Journal of Animal Sciences 25: 1015-1020.

Zhao X, Guo Y, Guo S and Tan J (2013a). Effects of Clostridium butyricum and Enterococcus faecium on growth performance, lipid metabolism, and cecal microbiota of broiler chickens. Applied Microbiology and Biotechnology 97: 6477-6488.

Zhao XH, He X, Yang XF and Zhong XH (2013b). Effect of Portulaca oleracea extracts on growth performance and microbial populations in ceca of broilers. Poultry Science 92: 1343-1347.

Zhang ZF and Kim IH (2014). Effects of multistrain probiotics on growth performance, apparent ileal nutrient digestibility, blood characteristics, cecal microbial shedding, and excreta odor contents in broilers. Poultry Science 93: 364-370.

Zhang KY, Yan F, Keen CA and Waldroup PW (2005). Evaluation of microencapsulated essential oils and organic acids in diets for broiler chickens. International Journal of Poultry Science 4: 612-619.

Zhang HY, Piao XS, Zhang Q, Li P, Yi JQ, Liu JD, Li QY and Wang GQ (2013). The effects of Forsythia suspensa extract and berberine on growth performance, immunity, antioxidant activities, and intestinal microbiota in broilers under high stocking density. Poultry Science 92: 1981-1988. 